\title{
Essay
}

\section{Local Policing After the Terror}

\author{
William J. Stuntz ${ }^{\dagger}$
}

\section{CONTENTS}

INTRODUCTION

I. Constitutional Protections and CRime Rates
A. Why Fourth and Fifth Amendment Protections Should

Fluctuate with Crime.

B. Past Practice and September 11

II. OfFering Greater Power, Requiring Greater RESTRAINT .....2160
A. Profiling
1. Searching and Seizing Groups
2. Regulating the Manner of Individual Searches and Seizures
3. Profiling as a Second-Best Problem..................................2176

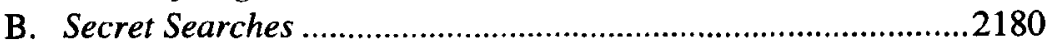

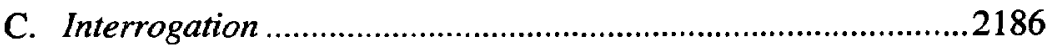

III. CONCLUSION: THE PROMISE OF A GRAND TRADE

$\dagger$ Professor, Harvard Law School. I thank Ron Allen, David Barron, Michele Cotton, Anne Coughlin, Einer Elhauge, Heather Gerken, Bernard Harcourt, Mike Klarman, Daryl Levinson, Debra Livingston, Richard McAdams, Dan Meltzer, Mark Moore, Dan Richman, Jim Ryan, Margo Schlanger, Mike Seidman, and Carol Steiker for helpful comments on previous drafts. I also thank participants in workshops at the Harvard Interdisciplinary Crime Policy Group and the University of Illinois College of Law for insightful questions that shaped my thinking on this subject. Finally, I am indebted to Brent Bickley, Matt Iverson, and Henry Whitaker for fine research assistance. 


\section{INTRODUCTION}

Crime waves always carry with them calls for more law enforcement authority. What happened on September 11, 2001 was, among other things, a crime wave--because of that one day, the number of homicides in America in 2001 will be twenty percent higher than the year before. ${ }^{1}$ It is no surprise, then, that even before the fires in the rubble that was the World Trade Center burned themselves out, some politicians were calling for broader powers for law enforcement and greater restrictions on citizens, all in the effort to fight this particular crime wave.

That is not a bad thing. Law enforcement authority naturally varies with the nature and size of the crime problems police must combat. A glance at the recent history of criminal procedure shows as much. Most legal restrictions on policing date from the criminal procedure revolution of the 1960 s, which itself can be seen as a consequence of the low-crime 1950s. Higher crime rates led to cutbacks in those legal protections in the 1970s and 1980s, just as lower crime rates have led to some expansion in the past few years. In short, Fourth and Fifth Amendment rights have varied with crime before, and they will probably do so in the future. As they must, if the law is to reflect a sensible balance between the social need for order and individuals' desire for privacy and liberty. The terrorist attacks on New York and Washington raised the demands on law enforcement. Those increased demands have already led to some increases in law enforcers' legal authority, and that trend will-and probably should-continue, at least for a while.

It helps to separate these legal changes (both the ones we have already seen and the ones likely to come in the near future) into two categories: special powers that are limited to the fight against terrorism, and changes in the authority of police across the board. The first is the product of federal legislation, ${ }^{2}$ and thus affects only a small fraction of the more than 800,000

1. According to FBI figures, there were 15,517 murders in 2000 , almost exactly the same as the 15,522 murders in 1999. Press Release, Fed. Bureau of Investigation, Crime in the United States, 2000 (Oct. 22, 2001), http://www.fbi.gov/pressrel/pressrel01/cius2000.htm. Assuming a similar figure absent what happened on September 11, the more than 3000 people killed in the attacks on that date would represent a twenty percent increase. See Associated Press, Official Count of Sept. 11 Victims, N.Y. TIMES, Apr. 8, 2002, at http://www.nytimes.com/aponline/ national/AP-Attacks-Toll-Box.html (placing the official count of the victims at 3062). The official count is likely to understate the number of deaths because illegal immigrants who died in the World Trade Center collapse may never be counted. See Charlie LeDuff, For Some, Lives in the Shadows Ended in Attack, Indiscernibly, N.Y. TIMES, Dec. 30, 2001, \& 1B, at 1.

2. The major piece of legislation thus far is the Uniting and Strengthening America by Providing Appropriate Tools Required To Intercept and Obstruct Terrorism Act of 2001, Pub. L. No. 107-56, 115 Stat. 272 [hereinafter USA PATRIOT Act]. 
law enforcement officers in the United States. ${ }^{3}$ The second is, or will be, the product of judicial decisions, for it is judges who determine the scope of Fourth and Fifth Amendment law, and it is those bodies of law that constrain the great majority of those 800,000 -plus officers. The first category has gotten the most ink thus far, but the second category is more important. The sheer size of America's local law enforcement machinery means that the rules that bind it have much more to do with the amount of freedom most Americans possess than the rules that limit the power of FBI agents.

The subject of this Essay is that second category. At first blush, one might wonder whether the category will even exist. Why, after all, should the war on terrorism lead to change in the doctrines governing ordinary searches and seizures when Congress has already created targeted authority for fighting terrorists? The answer comes in three parts. First, some antiterrorism legislation is not so targeted after all: Some of the extra powers Congress has granted the FBI are general, not limited to the fight against al Qaeda. ${ }^{4}$ Courts will be called on to assess the constitutionality of these provisions as a general matter, not just as applied to a particular crime problem. If they are upheld, state and local governments can be expected to copy them.

Second, the domestic war on terrorism is already affecting local police departments' ability to deal with more typical sorts of crime. A lot of police manpower has been diverted to various forms of homeland security, such as guarding at-risk public spaces and responding to reports of possible attacks. ${ }^{5}$ That drains resources from more ordinary policing, which may in turn lead to an increase in crime generally-some cities have seen sharp increases in homicides since September $11 .^{6} \mathrm{~A}$ general crime rise would

3. See Sourcebook OF Criminal Justice Statistics-1998, at 31 tbl.1.2 (Kathleen Maguire \& Ann L. Pastore eds., 1999) (showing 747,878 state and local police full-time equivalents); Daniel C. Richman, The Changing Boundaries Between Federal and Local Law Enforcement, 2 CRIM. JUST. 81, 82 (2000), http://www.ojp.usdoj.gov/nij/criminal_justice2000/ vol2_2000.html (showing that roughly 75,000 officers work for some federal law enforcement agency).

4. See infra notes $132-138$ and accompanying text.

5. See, e.g., Clyde Haberman, Visions of a Long Struggle, Strains on Police and Help for Victims, N.Y. TimES, Oct. 27, 2001, $\$ 1 \mathrm{~B}$, at 1 ("Forced to respond to anthrax reports, bomb scares and the like, the police are now rethinking how much effort they can spend on the tactics that reduce crime."); Michael Janofsky, A Nation Challenged: The Police; Anthrax Scares Are Stretching Thin Blue Line, N.Y. TIMES, Oct. 18, 2001, at B10 (noting budget strains in several police departments due to responses to anthrax scares and extra sccurity at public events).

6. See Fox Butterfield, Killings Increase in Many Big Cities, N.Y. TIMES, Dec. 21, 2001, at A1 (noting post-September 11 rises in crime in New York, Baltimore, and Washington); Haberman, supra note 5 (noting a sharp rise in homicides in Philadelphia in September 2001, with Philadelphia's police commissioner blaming the rise on the need to shift narcotics detectives to street patrol in Center City). Even if the diversion of police resources does not cause a general rise in crime, it may reinforce a crime rise that was already underway before September 11. See Butterfield, supra (noting sharp rises in homicides in a number of other major cities during 2001). 
naturally lead to calls for fewer legal restrictions on the police, as it did in both the 1960s and the 1980s. Such calls are likely even if we manage to avoid a post-September 11 surge in crime: Lowering the level of legal regulation would permit police to do the rest of their jobs more cheaply, leaving more time and personnel to devote to security against further terrorist attacks. This is a particular instance of a general point: A sharp rise in one kind of crime inevitably generates demand for greater authority to deal with other crimes.

Third, most constitutional limits on policing are transsubstantive-they apply equally to suspected drug dealers and suspected terrorists. ${ }^{7}$ A number of scholars have bemoaned this fact, ${ }^{8}$ but it remains a fact, and there is no reason to believe that current exigencies will change it. It follows that when courts approve police tactics designed to fight terrorists, they will also be sanctioning use of the same tactics against other sorts of criminals. And the transsubstantive nature of American criminal procedure matters in another important way: Judges and Justices are likely to think about the effect of their decisions on the fight against terrorism even when the underlying cases involve more ordinary sorts of policing. We have seen this before. One cannot read Fourth Amendment cases from the 1980s without sensing judicial attention to the pros and cons of the war on drugs-even when the cases did not involve drug crime. Crack dealers were the most salient crime

7. The Fourth Amendment requires probable cause for most searches and seizures; that standard incorporates the entire criminal code without differentiation. See, e.g., Atwater v. City of Lago Vista, 532 U.S. 318 (2001) (authorizing custodial arrest for the nonjailable crime of driving without a seat belt). The Fifth Amendment's privilege against self-incrimination applies whenever a witness is compelled to answer questions that, if answered truthfully, might submit him to criminal liability. What is "criminal" for these purposes depends on the legislature's classification. See, e.g., United States v. Ward, 448 U.S. 242 (1980) (holding that the line between criminal and noncriminal offenses is one of statutory interpretation).

8. The best and most famous bemoaning comes not from a scholar but from a Supreme Court Justice:

[I]f we are to make judicial exceptions to the Fourth Amendment ..., it seems to me they should depend somewhat upon the gravity of the offense. If we assume, for example, that a child is kidnaped and the officers throw a roadblock about the neighborhood and search every outgoing car, it would be a drastic and undiscriminating use of the search. The officers might be unable to show probable cause for searching any particular car. However, I should candidly strive hard to sustain such an action, executed fairly and in good faith, because it might be reasonable to subject travelers to that indignity if it was the only way to save a threatened life and detect a vicious crime. But I should not strain to sustain such a roadblock and universal search to salvage a few bottles of bourbon and catch a bootlegger.

Brinegar v. United States, 338 U.S. 160, 183 (1949) (Jackson, J., dissenting). For more contemporary variations on this theme, see Sherry F. Colb, The Qualitative Dimension of Fourth Amendment "Reasonableness," 98 COLUM. L. REV. 1642 (1998); David A. Sklansky, Traffic Stops, Minority Motorists, and the Future of the Fourth Amendment, 1997 SUP. CT. REV. 271; and William J. Stuntz, O.J. Simpson, Bill Clinton, and the Transsubstantive Fourth Amendment, 114 HARV. L. REV. 842 (2001) [hereinafter Stuntz, Simpson and Clinton]. For a similar argument directed not only to the Fourth Amendment but also to the whole of criminal procedure, see William J. Stuntz, Substance, Process, and the Civil-Criminal Line, 7 J. CONTEMP. LEGAL IssuES 1 (1996). 
problem a dozen years ago; now, terrorists occupy that place. And if the war on terrorism has half the effect on Fourth Amendment law that the war on drugs had, the effect will be large indeed.

For all these reasons, Fourth and Fifth Amendment law is likely to move toward greater authority for the police-not just for the FBI, and not just when fighting terrorists. The natural conclusion is that we will see a loss of individual liberty and privacy. After all, this tradeoff seems to be zero-sum. Giving ground on one side means losing ground on the other.

Yet that need not be so. As things stand now, the law that polices the police is at once too lax and too strict. It both limits police in the wrong ways and leaves them free to do the wrong things. Some of these dysfunctional features appear precisely in areas where the fight against terrorism is most likely to place pressure on the law. In the wake of September 11, these conditions present a large opportunity. It may be possible, by fixing some of the law's worst mistakes, to give the police more power while also giving citizens more liberty and privacy-a Pareto move in a sphere where such moves are rare. Now may be the time for a grand trade--greater power to catch criminals coupled with rules that limit the harm greater power can do.

My chief goal in this Essay is to suggest the outlines of such a trade. It has four elements. First, give police the power to seize or search groups, ${ }^{9}$ with or without any grounds for suspecting individual members of those groups. That sounds like, and is, a large gift. Yet it is also a bribe (of the healthy sort), a means of inducing police to substitute less harmful and more self-regulating tactics for more harmful and harder-to-regulate ones. Second, give police the power (more precisely, let them keep the broad power they already have) to stop and question individual suspects based on slight suspicion, but regulate the manner of those encounters more seriously. Right now, Fourth Amendment law devotes an enormous amount of attention to the fact of searches and seizures, but almost none to how those searches and seizures are carried out. That ought to be reversed; sharp legal lines between "searches" and "seizures" and everything else ought to be replaced with hazier boundaries between decent police behavior and the indecent kind. Those two changes would have a number of good effects; among other things, they might substantially reduce the harm caused by racial profiling-the practice of selecting targets of police attention based in part on race or ethnicity.

Third, give police greater power to gather information, but couple that gift with restrictions on how the information is used once it is gathered. It is

9. For purposes of my argument, groups are defined by time and place, not by demographic category. Thus, the temporary seizure of all cars passing through a given intersection on a given afternoon is a "group seizure," as I use that phrase. The seizure of all young men of Middle Eastern origin, without regard to time or place, is not. 
one of the law's great peculiarities that privacy tends to be protected either absolutely or not at all-either no one can see the contents of my glove compartment or the police can both see it and put it on the evening news. Graded protection would make more sense, by giving police greater power to catch criminals while still guarding against the worst privacy intrusions. Fourth, give police the ability to question all arrestees, even those who have invoked their Miranda rights, but couple that with a requirement that interrogation be video- and audiotaped, so that courts can review police questioning for evidence of coercion. Current Miranda doctrine overprotects a few suspects-the few who are savvy enough to invoke their rights (and thereby opt out of questioning) - and underprotects the rest. Case-by-case review with tapes of interrogation sessions would be fairer.

Notice that racial profiling appears only indirectly on this list of proposed reforms. That might seem like a dodge. In terms of how we police the police, profiling is the great issue of our time. There was already a lively debate about it before September 11 , and the mass murder that took place on that date only served to make that debate more important. Any responsible discussion that aims to reform Fourth Amendment law should, one might think, grapple with this issue. But profiling is an issue best solved by indirection. If confronted directly, it is intractable-easy to forbid in theory, impossible (and maybe inadvisable) to root out in practice, for reasons that go to the heart of why police officers do the things they do. At the same time, the size of the problem might be reduced significantly if the law did two things it does not presently do: Make alternatives to profiling cheaper for the police, and reduce the harms profiling causes when it happens. Those steps would not solve the problem-maybe they would not come close to solving the problem-but with unsolvable problems, mitigation of harm is a worthy goal.

The Essay proceeds as follows. Part I defends the proposition that the scope of Fourth and Fifth Amendment rights does and should vary (and has varied in the recent past) with crime rates. In other words, there is nothing new about, and nothing wrong with, the claim that after September 11 law enforcement authority should increase. Part II then deals with the ways that power could increase while minimizing harm to the citizenry, focusing on the elements of the trade outlined above, and, in particular, on the ways in which these legal changes might be the best available option for dealing with racial profiling. Part III concludes with a brief discussion of the feasibility of a constitutional trade like the one I suggest here.

\section{CONSTITUTIONAL PRotections AND CRIME RATES}

The subject of this Essay is the scope of the constitutional rights that constrain the police-the rights to be free from unreasonable searches and 
seizures and compelled self-incrimination. A common assumption among those who think and write about such rights is that they have a correct shape and size that hold constant over time. Notice the word "correct." The scope of Fourth and Fifth Amendment rights, like the scope of other constitutional protections, of course changes in every time period and in every possible direction. But most constitutional argument assumes that there is a normatively right answer to the question what the scope of these rights should be, and that the answer is basically fixed. ${ }^{10}$

There may be a particularly strong tendency to hold to that position in the law of criminal procedure, for a reason that surfaces not in criminal procedure scholarship but in the literature on the First Amendment. Vince Blasi has argued that the real utility of constitutional protection for free speech is its ability to halt the slide toward repression in paranoid times. ${ }^{11}$ The implication is that context-- changes in social circumstances that might lead to arguments for changes in the scope of the right-is something to be resisted when defining the bounds of constitutional rights, not something to be incorporated into legal analysis. Blasi's idea has a lot of adherents because it has a lot of intuitive force-think of McCarthyism-and it is easy to see its appeal in criminal procedure. Perhaps especially when the public is clamoring for something to be done about some new crime

10. As the assumption is usually both implicit and undefended, the point is hard to prove. In the case law, the best examples are the two cases from which modern Fourth and Fifth Amendment doctrines spring: Mapp v. Ohio, 367 U.S. 643 (1961), and Miranda v. Arizona, 384 U.S. 436 (1966). Both Mapp and Miranda rest their (revolutionary) holdings on arguments that stand outside context-Mapp, on the "imperative of judicial integrity," 367 U.S. at 659 (internal quotation marks omitted); Miranda, on the proposition that confessions made by a suspect uninformed of his rights are necessarily compelled. To be sure, the Miranda Court did care a great deal about context in one sense: The bulk of the Court's opinion is devoted to establishing that a particular context, stationhouse questioning, is inherently coercive. But the key is the word "inherently." Nothing in Miranda (and nothing in Mapp) suggests that the result should change if social circumstances changed.

Much has changed in Fourth and Fifth Amendment law since Mapp and Miranda, but this feature of the Court's decisions-more precisely, of the Court's rhetoric-has been remarkably durable. The best evidence of this is the noteworthiness of the occasional exceptions, cases in which one or more Justices actually say that the rule should perhaps be different if circumstances change. E.g., United States v. Leon, 468 U.S. 897, 927 (1984) (Blackmun, J., concurring) (noting the "unavoidably provisional nature" of the Court's decision).

For the Court, this posture is basically rhetorical. Social context matters, but stays under the table; opinions must be couched in terms of acontextual principle. For scholars, the idea runs deeper-though more so for the Fourth Amendment than for Miranda. With respect to police interrogation, there has been a lively debate about empirics, see Richard A. Leo, Questioning the Relevance of Miranda in the Twenty-First Century, 99 MICH. L. REV. 1000 (2001) (summarizing that debate), but the Fourth Amendment literature has not shared that empirical orientation. In that literature, the facts of the cases tend to matter a lot, but the facts in a broader sense-the effects of different legal rules under different social circumstances-tend to matter a good deal less. For a strong and persuasive criticism of the literature on this point, see Ronald J. Allen \& Ross $\mathbf{M}$. Rosenberg, The Fourth Amendment and the Limits of Theory: Local Versus General Theoretical Knowledge, 72 ST. JOHN's L. REV. 1149 (1998).

11. Vincent Blasi, The Pathological Perspective and the First Amendment, 85 COLUM. L. REV. 449 (1985). 
problem, we should hold the line against any change in the scope of protection against police abuse, lest a temporary clamor produce a permanent loss of freedom.

And so, either because we usually think of rights as constants, or because we think that some kinds of rights should never vary in response to public outcry, the tendency is to think that rights like those contained in the Fourth and Fifth Amendments should not change in response to events like those of September 11, 2001. That tendency is wrong. It is also futile: The scope of these rights is, has been, and will be responsive to changes in context. It follows that the productive move for those who value civil liberties is not to resist change, but to strive to produce good change instead of bad.

\section{A. Why Fourth and Fifth Amendment Protections Should Fluctuate with Crime}

The tendency is wrong because of the nature of the rights, or more precisely, because of the nature of their consequences. In a nutshell, the problem is this: The police help to restrain crime. Rules that restrain the police thus tend to remove restraints on crime. There is a tradeoff between more restraints on the police and more restraints on crime. One could ignore the tradeoff when defining the relevant rights, but it is not clear why one would want to. The more natural course of action is to look to the competing concerns and try to strike a sensible balance, taking account of changes in the nature and incidence of crime.

Begin with the two most plausible visions of rights like those contained in the Fourth and Fifth Amendments. The first treats them the way we treat most rights-as principled protections of a sphere of individual privacy and autonomy, boundaries that the government may not cross save in exceptional circumstances. If one buys that vision, one will tend to look askance at arguments that the law of search and seizure or police interrogation ought to give a little more ground to the police in some times and a little less in others. To paraphrase John Marshall, these are rights we are talking about ${ }^{12}$-and rights have a certain nature that excludes the possibility that they will be defined by some general balancing of interests.

The second vision treats Fourth and Fifth Amendment rules as tools for policing the police, as a kind of tort law for law enforcers. Tort law is usually seen as instrumental; in Guido Calabresi's classic formulation, it is a means of minimizing the sum of the costs of accidents and the costs of

12. Cf. McCulloch v. Maryland, 17 U.S. (4 Wheat.) 316, 407 (1819) ("[W]e must never forget that it is a constitution we are expounding."). 
avoiding them. ${ }^{13}$ That formulation fits naturally into criminal procedure's framework: One might see most constitutional limits on law enforcement as aimed at minimizing the sum of the costs of crime and the costs of crime prevention. More rigorous constraints on police searches and seizures might reduce the cost of crime prevention but raise the cost of crime; loosen the restraints, and the cost of crime will drop while the cost of prevention rises.

The essence of the second vision is the tradeoff between police power, which always carries the potential for abuse and injury, and crime, which inflicts its own injuries. If the tradeoff does not exist-if police have no effect on crime levels-the first vision is clearly the better one. ${ }^{14}$ But the reality is that police do affect the level of serious crime. The evidence we have suggests that hiring more police officers tends to reduce the crime rate. ${ }^{15}$ It seems a small step from that proposition to the claim that making officers more productive probably tends to reduce the crime rate. Legal restraints tend to lower police productivity; they prevent cops from doing things that (at least according to the cops) are cost-effective and force them to substitute less efficient tactics. That is not to say the restraints are badlower productivity is well worth it if the alternative is a police state. It $i$ to say that restraints on the police are likely to have some cost in crime. Defining the restraints without reference to their cost seems strange.

The cost is likely to fluctuate as the nature and incidence of crime fluctuates. Or, to put the point more precisely, a rise or fall in serious crime seems a decent proxy for a rise or fall in the value of additional increments of police authority. This is so for two reasons. The first one has already been mentioned: It seems reasonable to assume that more police authority is valuable in fighting crime. Fourth Amendment law plainly rests on that assumption; if the assumption is wrong, a great many things in the law of criminal procedure need rethinking, not just the argument advanced here. The second reason is a little more complicated. Restrictions on police authority act as a tax; they make criminal investigation more expensive than it otherwise might be. ${ }^{16}$ When the crime rate is high, the taxed behavior is more valuable - in a high-crime, target-rich environment, a given number of man-hours of police work will be more productive than in a low-crime environment. When police work becomes more productive, the social cost

13. E.g., Guido Calabresi \& Jon T. Hirschoff, Toward a Test for Strict Liability in Torts, 81 YALE L.J. 1055, 1084 (1972).

14. More to the point, if the police have no effect on crime, we should seriously think about whether we want to have police forces in the first place.

15. See Steven D. Levitt, Using Electoral Cycles in Police Hiring To Estimate the Effect of Police on Crime, 87 AM. ECON. REv. 270 (1997); Thomas B. Marvell \& Carlisle E. Moody, Specification Problems, Police Levels, and Crime Rates, 34 CRIMINOLOGY 609 (1996).

16. I have elaborated on this point elsewhere. See William J. Stuntz, The Distribution of Fourth Amendment Privacy, 67 GEO. WASH. L. REV. 1265, 1274-77 (1999). 
of taxing it rises. Again, there is no obvious reason why one would wish to ignore that effect.

As a practical matter, ignoring it may be impossible. Return to the first vision of Fourth and Fifth Amendment rights, and consider the nature of the interests those rights protect. Privacy, the ability to hold what one rightfully possesses (either things or spaces), freedom from restraint, freedom from physical force (including deadly force), the ability to decide for oneself what to say and what not to, freedom from harassment, the ability to go about one's business in peace-all these things are protected, at least to some degree, against police invasion. Now consider the interests that criminals invade. The list is much the same. Police break down doors and invade people's homes; so do burglars. Police sometimes beat or shoot people; so do violent criminals. Police coercion cannot be seen in isolation from the coercion it seeks to combat, as citizens face risks of coercion from a mix of government officials and private (bad) actors. To say that one has a right to be free from coercion is to speak nonsense. Risks of coercion are everywhere; the law's only real option is to try to balance the risks-or, to speak in more Calabresian terms, to minimize their sum.

To put it another way, the "rights" vision of Fourth and Fifth Amendment law rests on an implausible assumption: that people care a lot about assaults and invasions by the police but care little about similar assaults and invasions by private parties. To be sure, there are reasons to care about the kind of power police officers have that do not apply to criminals' power to prey on their victims. Even so, everyone does and should care about both. After all, the state of nature-a world free of all risks of police coercion-is an unhappy place in many of the same ways that a police state is an unhappy place.

That is why the conventional balancing "test" in Fourth Amendment law misperceives the situation. The Supreme Court often says that Fourth Amendment law represents a balance of individual privacy against law enforcement need. That may be a fair stand-in for the real balance, but it is at least a little misleading. As Silas Wasserstrom and Louis Michael Seidman note, individual privacy is on both sides of that balance- "law enforcement need" is just another way of defining the protection of a kind of individual privacy against predation by criminals. ${ }^{17}$ Fourth Amendment law (and police interrogation doctrine) must be about the business of ensuring that, in containing the predators, we do not make for even worse predation. ${ }^{18}$

17. See Silas J. Wasserstrom \& Louis Michael Seidman, The Fourth Amendment as Constitutional Theory, 77 GEO. L.J. 19, 63-67 (1988).

18. This is a variant on a familiar argument. One might say that more govemment power always means less private power, and vice versa. "Rights" questions are thereby transformed into 
At the heart of that business lie circumstance-specific tradeoffs: In this society, with these suspects and police officers and these crime problems, where is the line to be drawn? Change one side of the balance-say, dramatically increase the risk of mass murder-and the point at which the two sides are in equipoise changes. It would seem to follow that if serious crime rises, police authority ought to increase, and if serious crime falls, it ought to decrease.

The most plausible challenge to this conclusion starts with the proposition that there is more than one way to adapt to changed circumstances: Changing budgets and police tactics may be an alternative to changing the legal controls on the police. Perhaps the best way to respond to a crime rise, whether occasioned by terrorism or anything else, is to hire more cops. ${ }^{19}$ Unsurprisingly, that has been a key element in the effort to upgrade airport security in the wake of the terrorist attacks on New York and Washington. Meanwhile, one of the best ways to respond to any change is to innovate-to see whether it is possible to improve performance even while advancing compliance with the law. Something like that may have happened to police interrogation in the wake of Miranda, as police officers shifted from coercive interrogation tactics to deceptive ones-a change that both improved the quality of interrogation and reduced the level of police coercion. ${ }^{20}$

tradeoffs: Which kind of institution do you want pushing you around, a private corporation or a government agency?

I am sympathetic to this line of argument generally, but even those who do not usually sympathize with it should do so here; the argument is more powerful in criminal procedure than in other settings. Take free speech rights. Banning government prohibitions on, say, peaceful picketing does not have the natural effect of increasing restraints on speech by private actors. It simply means fewer restraints on speech. The same is true of a rule barring the criminalization of some kinds of political views. Again, such a rule does not tend to produce equivalent private limits, but simply produces more freedom. (Campaign finance regulation is an exception to this pattern.) Many rights controversies work that way; they are not tradeoffs between restraint from one source and restraint from another, but are simply choices about whether to have more restraint or less.

Criminal procedure is different because tradeoffs are the rule, not the exception-and the same interests are being traded off for one another. Reduce police power to search, seize, and arrest, and you reduce the cost of committing the crimes police investigate, which will tend to mean that more such crimes are committed. The same is true of restrictions on police interrogation. To be sure, sometimes police can be given more authority without taking away individual freedom-in Part II of this Essay, I suggest several legal changes that would, I believe, lead to gains in both law enforcement power and individual liberty. Other changes are positivesum, in the sense that the gains in freedom on one side outweigh the losses on the other. But for most changes, one can reasonably start with the following pair of assumptions: There are both gains and losses, and they are in the same currency. In such a world, to choose legal rules without reference to the tradeoffs seems akin to madness.

19. There is good reason to believe that hiring more police officers does indeed tend to reduce crime. See sources cited supra note 15.

20. See, e.g., Richard A. Leo, From Coercion to Deception: The Changing Nature of Police Interrogation in America, in THE MIRANDA DEBATE 65 (Richard A. Leo \& George C. Thomas III eds., 1998). 
This argument has a good deal of force, but it has two important weaknesses. First, it assumes that the law is likely to reach sound and durable bottom lines-rules that strike wise balances across a wide range of contexts. If that were so, if the legal standards governing search and seizure and interrogation represented some principled desideratum, then it would be wise to hold to those standards and let budgets and tactics adapt when circumstances change. Needless to say, it isn't so. Even if there were an obviously right set of lines to draw when regulating searches and seizures and police questioning of suspects, appellate judges lack the capacity to identify and draw those lines; they have neither enough information nor the right kind of training.

Second, budgets and tactics may be less adaptable than legal standards. This seems counterintuitive. Constitutional law changes slowly, or so one might suppose, while the behavior of the city council members who define police budgets and the police chiefs who spur tactical innovation can turn on a dime with every new election. Yet it is probably true. The constitutionalization of criminal procedure means that the law in this area is remarkably centralized. ${ }^{21}$ Five Supreme Court Justices can change the relevant standards as and when they choose; in the span of a few years they can revolutionize the doctrine, changing a wide range of liability rules and remedial regimes-as they did between 1961 and $1966 .^{22}$ Police budgets and police tactics are radically decentralized, given that the great majority

21. On balance, centralization is probably a bad thing. It tends to increase the role of legal theory in the law of criminal procedure, which raises error costs. See Allen \& Rosenberg, supra note 10. It also increases the importance of the Supreme Court, which likewise raises error costs, given the Justices' limited understanding of local criminal justice systems. Nevertheless, for all its flaws, centralization does have one large advantage-it permits easy adaptation to changed circumstances.

This point is not limited to the law of criminal procedure. Constitutional law generally is remarkably centralized, and hence unusually adaptable to changed circumstances. One implication may be that even a weak norm of stare decisis is a bad idea in constitutional litigation. Those judges and academics who seek stability in constitutional doctrine are giving away one of the system's largest virtues.

22. See, e.g., Monroc v. Pape, 365 U.S. 167 (1961) (broadening damages liability for constitutional violations); Mapp v. Ohio, 367 U.S. 643 (1961) (applying the exclusionary rule to state cases); Massiah v. United States, 377 U.S. 201 (1964) (banning some forms of uncounseled police questioning); Malloy v. Hogan, 378 U.S. 1 (1964) (applying the privilege against selfincrimination to state cases); Beck v. Ohio, 379 U.S. 89 (1964) (enforcing the probable-cause-toarrest standard); Shuttlesworth y. Birmingham, 382 U.S. 87 (1965) (invalidating a vague loitering law); Miranda v. Arizona, 384 U.S. 436 (1966) (instituting a system of warning and waiver rules to govern custodial police interrogation). This list includes only cases that substantially affected the liability rules or remedies for police misconduct; if one broadens the field of vision to include the rest of criminal procedure, the list is much longer. See infra notes 166-176 and accompanying text. Among other things, the cases just cited show that multimember appellate courts are capable of manipulating a number of legal variables simultaneously, or nearly so. 
of officers work for and are paid by local governments. ${ }^{23}$ Getting productive change to work its way through that system is a hard and slow process. ${ }^{24}$

Finally, to the extent that legal restrictions impose budgetary costs on police departments, they may have unpleasant distributive consequences. Policing is redistributive-its benefits flow disproportionately to the poor, while its monetary costs (i.e. taxes) are felt disproportionately by the middle and upper classes. Meanwhile, for at least the past forty years, crime in the United States has been heavily concentrated in cities. ${ }^{25}$ Put those two facts together, and a problem emerges: It is easy for the well-to-do to move out of cities and thereby spare themselves the cost of paying for the redistributive services cities provide, including policing. Anything that raises the monetary cost of running a police department tends to aggravate that problem. Increase police budgets and taxes must increase; raise taxes and well-off taxpayers will flee to the suburbs. Holding the line on legal standards in times of rising crime may raise police budgets. If police must deal with more crime and must meet the same legal standards while doing so, they are likely to need to spend more money.

Meanwhile, some legal rules are not just expensive; they are disabling. Miranda doctrine bars questioning suspects who have invoked their right to counsel. ${ }^{26}$ This is not a large problem when the police are dealing with the eighty percent of suspects who agree to talk to the police after receiving the famous warnings. ${ }^{27}$ It is likewise no problem when there are other, easily available sources of evidence besides the suspect's own statements-as in routine drug cases where the drugs themselves make the government's case. But imagine a crime that is serious (so that it must be investigated and, if at all possible, solved), imagine that to solve this crime police need information from the criminals who commit it (so that interrogation of suspects is a must), and imagine further that the people who commit this crime are more savvy than most suspects (so that they know enough to invoke their rights when questioned). Under these circumstances, no

23. See supra note 3 .

24. It is also a process in which politics intervenes in some inconvenient ways. A healthy adaptation of police budgets to circumstances would see more officers hired when crime goes up and some attrition of the police force when crime goes down. The best study of police hiring and crime rates suggests that police hiring responds not to changes in crime but to election cycles. See Levilt, supra note 15.

25. Historians generally use homicide rates as a proxy for rates of serious crime because homicide data are so much better than data for other crimes. Eric Monkkonen has shown that New York City's homicide rate was lower than the homicide rate for the United States as a whole until the late 1950s; since then, New York's homicide rate, which is not among the highest of American cities', has been vastly higher than the rate for the rest of the country. See Eric Monkkonen, Homicide over the Centuries, in THE CRIME ConUndrum 163, $166-67$ \& fig.l (Lawrence M. Friedman \& George Fisher eds., 1997).

26. Minnick v. Mississippi, 498 U.S. 146 (1990); Edwards v. Arizona, 451 U.S. 477 (1981).

27. The best study to date finds a waiver rate of just under eighty percent. See Richard A. Leo, The Impact of Miranda Revisited, 86 J. CRIM. L. \& CRIMINOLOGY 621, 653 (1996). 
amount of investigation can overcome the legal barrier. The police must either immunize the suspects or disobey the legal rule in order to get information from them-and immunity is expensive, since the police may not know which suspects are the major players and which are the small fry. Notice that each of these conditions may apply to some kinds of terrorism. The social cost of Miranda may have risen dramatically on September 11.

There is something perverse about not taking that social cost into account. It follows that changes in the world of crime ought to be taken into account when considering the merits of the many legal rules that govern policing.

\section{B. Past Practice and September 11}

Whether or not it should, the law of criminal procedure plainly does change in response to changes-both qualitative and quantitative-in crime. An example of the qualitative sort involves Fourth Amendment law's treatment of confidential informants. The basic scenario in these cases is as follows: An informant tells the police that a given suspect will behave in particular ways at particular times (the tip usually specifies things like travel patterns and dress), and also that the suspect will be carrying drugs. ${ }^{28}$ (The last element is not just a detail. The large majority of cases in which tips are used to obtain search warrants are drug cases, and the police departments that conduct the most drug searches also make the most use of informants. ${ }^{29}$ ) The issue, whether the tip gives the police authority to search or arrest, turns on how the law treats corroboration. If the police corroborate the innocent parts of the tip-what clothing the suspect would be wearing, where he would be going and when - can they then trust the guilty part, the claim that the suspect would be carrying drugs $?^{30}$ In 1969, in Spinelliv. United States, the Supreme Court said no: Corroboration of innocent details is not enough to validate a tip; the police must show that the informant is

28. Most of the leading Supreme Court cases on the subject follow this fact pattern. See Draper v. United States, 358 U.S. 307 (1959); Illinois v. Gates, 462 U.S. 213 (1983); Alabama v. White, 496 U.S. 325 (1990). The two major exceptions are Spinelli v. United States, 393 U.S. 410 (1969), where the crime was gambling instead of drugs, and Florida v. J.L., 529 U.S. 266 (2000), wherc the alleged behavior-possession of a concealed weapon-was not necessarily a crime at all. Perhaps it is more than a coincidence that the defendants in Spinelli and J.L. won, while their counterparts in the three drug cases-Draper, Gates, and White-lost.

29. See Richard Van Duizend et al., The Search Warrant Process 33, 44 tbl.2-14 (1985).

30. For the sake of simplicity, I have cut a few corners in the text. For a more detailed discussion of why corroboration is the key issue, see William J. Stuntz, Warrants and Fourth Amendment Remedies, 77 VA. L. REV. 881, 929-32 (1991). 
truthful and that his basis of knowledge is reliable. ${ }^{31}$ That made informants' tips nearly worthless as means of getting search warrants.

In 1969, drug cases were still a small part of most criminal dockets. (Two years later, drug cases represented fewer than five percent of state criminal charges.) $)^{32}$ In that environment, tough restrictions on the use of informants were not that costly. A decade later, the story was very different: Criminal dockets were exploding ${ }^{33}$ (placing pressure on police and prosecutors to find cheap ways to resolve cases), with drug cases fueling the explosion. ${ }^{34}$ The ability to use informants' tips had become much more valuable. Lower courts, in response, began to find ways to end-run Spinelli, ${ }^{35}$ and in 1983 the Supreme Court overruled it, putting in its place a consider-all-the-circumstances test that is much more informant-friendly. ${ }^{36}$ The most natural story to tell is that the law adopted a restrictive standard when the level of drug crime was low (or when drug crime was a low priority for law enforcement) and relaxed the standard when drug crime rose sharply. If ever we return to the level of drug arrests and prosecutions we saw in 1969, courts will likely push the standard higher, and Spinellilike rules will enjoy a comeback.

For a more quantitative example, consider the general scope of Fourth Amendment protection over the past forty years. By the mid-1950s crime had been declining for some time, and had fallen to a level we can only dream about today. ${ }^{37}$ A few years later, the Supreme Court effectively

31. 393 U.S. at $413-19$, overruled by Gates, 462 U.S. 213. The Spinelli Court did not squarely say that corroboration of the innocent details would not suffice to validate the tip-it would have been hard for the Court to say that without overruling Draper v. United States, 358 U.S. 307 (1958), in which such corroboration did validale the tip. But Spinelli came close, by finding the corroboration in that case (description of the suspect's travel pattern, use of an apartment other than his dwelling, and the apartment's two phone numbers) insufficient.

32. See Michael J. Hindelang ET AL., U.S. DEP'T Of Justice, SOURCEBook of Criminal JUSTICE STATISTICS-1973, at 325 tbl.5.32 (1973).

33. See NAT'l CTR. For State Courts, State Court Caseload Statistics: Annual REPORT 1984, at 189-90 tbl.35 (1986) (showing a thirty-six percent increase in felony filings from 1978 to 1984 ).

34. Between 1968 and 1988, drug arrests more than quintupled. See Robert Reinhold, Police, Hard Pressed in Drug War, Are Turning to Preventive Efforts, N.Y. TIMES, Dec. 28, 1989, at Al.

35. The most common end-run was to find that a strong showing on one of Spinelli's two prongs (the informant's veracity and her basis of knowledge) could overcome a weak showing on the other. See, e.g. United States v. Sellers, 483 F.2d 37 (5th Cir. 1973); United States v. Crawford, 462 F.2d 597 (9th Cir. 1972). This move effectively made the two-prong test into an either-one-or-the-other-prong test, which was a good deal easier for the government to satisfy.

36. See Gates, 462 U.S. 213.

37. On the fall in crime, sce, for example, Monkkonen, supra note 25, at 166-69. On the post1960 rise, the FBI's index crime numbers (the only source of nationwide crime data we have for the relevant time period) tell the story. The number of index crimes per 100,000 population in 1960 was 1126. FED. BUREAU OF INVESTIGATION, UNIFORM CRIME REPORTS FOR THE UNITED STATFS-1972, at 61 tbl.2 (1973) [hercinafter 1972 UNIFORM CRIME REPORTS]. In the 1970s, the method used for calculating the number of index crimes was changed, FED. BUREAU OF INVESTIGATION, UNIFORM CRIME REPORTS FOR THE UNITED STATES-1973, at 1 (1974); if one adjusts the 1960 figure accordingly, the rate rises to 1614. In 1999, after a decade in which index crimes had fallen by more than a quarter, the figurc was 4267 . FED. BUREAU OF INVESTIGATION, 
constitutionalized the law of search and seizure, both by imposing the exclusionary rule on state courts ${ }^{38}$ and by making officers potentially liable for damages for illegal searches and arrests. ${ }^{39}$ Crime rates turned up in the late 1950 s, slowly at first, then accelerating in the early to mid-1960s. ${ }^{40} \mathrm{By}$ 1968 , the number of violent crimes nationwide had more than doubled in the span of seven years. ${ }^{41}$ That same year, the Supreme Court inaugurated a generation-long turn toward more favorable rules for police with its decision in Terry v. Ohio, allowing brief stops and frisks based on reasonable suspicion of crime-a significantly softer standard than probable cause. $^{42}$

Notice the year. In 1968, Richard Nixon was not yet President. Earl Warren was still Chief Justice. Abe Fortas had not yet resigned in disgrace. The most recently appointed Justice was Thurgood Marshall, then finishing his first Term on the Court. If Terry represented a change in direction-and Warren's agonized opinion suggests he thought it did $^{43}$ - the change was not imposed by new personnel. The same Court that decided Miranda $v$.

UNIFORM CRIME REPORTS FOR THE UNITED STATES-1999, at 64 thl.1 (2000), http://www.fbi.gov/ucr/Cius_99/99crime/99c2_13.pdf. Even if one makes a generous allowance for changes in reporting practices, the difference is enormous.

38. See Mapp v. Ohio, 367 U.S. 643 (1961).

39. See Monroc v. Pape, 365 U.S. 167 (1961).

40. See 1972 UNIFORM CRIME REPORTS, supra note 37, at 61 tbl.2.

41. Id. (showing a rise in violent crimes from 286,880 in 1961 to 590,160 in 1968). It is tempting to conclude that these numbers reflect changes in reporting practices rather than a sharp rise in crime. And it is true that homicides, which are less subject to variations in reporting, rose less sharply during the same period, though the rise was still significant. Id. (showing a rise in the number of murders and nonnegligent manslaughters from 8660 in 1961 to 13,690 in 1968). On the other hand, auto thefts, which likewise are reported fairly consistently-victims need to report the thefts in order to collect on their insurance--rose even faster than violent crimes, from 333,700 in 1961 to 778,200 in 1968 . Id.

42. 392 U.S. 1 (1968). One could argue that Terry was not rcally a pro-police decision because the effective baseline before that case was not the probable cause standard. It had long been the case that police officers were able to stop and even arrest suspects without probable cause to believe the suspects had committed a "real" crime-the sort of crime for which offenders are frequently punished. See William O. Douglas, Vagrancy and Arrest on Suspicion, 70 YALE L.J. 1 (1960) (criticizing this state of affairs). By the time Terry was decided, courts were invalidating vagrancy and loitering laws, leaving a lot of searches and seizures subject to a serious probable cause standard where previously there had been no standard at all. Ohio, like a number of other states, felt a need to authorize stops and frisks through the statute challenged in Terry precisely because those stops and frisks were otherwise not authorized. In short, though the constitutional baseline against which Terry was decided was a moving target, the movement was very much in the direction of greater protection for suspects. Terry halted, and perhaps reversed, the movement.

43. See 392 U.S. at 10-15 (discussing the limits of the law's ability to rein in police misbehavior). On this score, it is helpful to compare Warren's opinion in Terry with his majority opinion in Miranda v. Arizona, 384 U.S. 436 (1966). Miranda is confident and aggressive; it betrays no concern for the cost or difficulty of the enterprise of regulating police interrogation. Terry is almost entirely about the cost and difficulty of regulating street stops. One cannot read the two opinions without sensing that something in the author's thinking changed between 1966 and 1968. 
Arizona,${ }^{44}$ a more liberal Court than the one that decided Mapp v. Ohio, ${ }^{45}$ decided in Terry that the needs of law enforcement required some compromise of the traditional probable cause standard. As Warren's law clerk Earl Dudley has put it:

Individually, the Justices of the Supreme Court may have felt differing degrees of sympathy with the arguments of the police, but collectively they were unwilling to be - or to be perceived as-the agents who tied the hands of the police in dealing with intensely dangerous and recurring situations on city streets. ${ }^{46}$

A decade of rising crime had had its effect.

Over the course of the next thirty years, this turn toward more propolice Fourth Amendment doctrine took two forms. Terry captures the first: The Court gave the police ever more leeway in brief street encounters. The bounds of a permissible Terry stop grew steadily broader over the course of the 1970s and 1980s-stops were permitted for drug crimes and minor crimes, not just violent crimes as in Terry, ${ }^{47}$ and for (suspected) past crimes,$^{48}$ not just the threat of future offenses as in Terry. More importantly, the Court made it ever easier to categorize an encounter as "consensual," and thereby not subject to any Fourth Amendment regulation at all ${ }^{49}$ These are natural responses to a sharp rise in crime rates, especially given that the rise was localized in cities. ${ }^{50}$ Street policing is largely an urban phenomenon. Reinforcing police authority to stop and question suspects was a logical way to adapt to a sharp rise in urban crime.

The second form involves the warrant requirement. In a long series of cases beginning with Chambers $v$. Maroney in $1970^{51}$ and extending, roughly, to California v. Acevedo in $1991,{ }^{52}$ the Court restricted that

44. 384 U.S. 436. The only change in personnel between Miranda and Terry was Tom Clark's resignation and Thurgood Marshall's appointment.

45. 367 U.S. 643 (1961). The Court that decided Mapp included six of the Justices who decided Terry: Warren, Black, Douglas, Harlan, Brennan, and Stewart. The other three Justices in 1961 were Frankfurter, Clark, and Whittaker. The other three Justices in 1968 were White, Fortas, and Marshall. That the Terry Court was somewhere to the left of the Mapp Court, at least in terms of its members' overall judicial ideologies, seems beyond serious argument.

46. Earl C. Dudley, Jr., Terry v. Ohio, the Warren Court, and the Fourth Amendment: A Law Clerk's Perspective, 72 ST. JOHN's L. REV. 891, 893 (1998).

47. In Terry, the suspected crime was robbery. 392 U.S. at 28 . On the application of Terry's analysis to suspected drug crime, see, for example, Alabama v. White, 496 U.S. 325 (1990). On its application to minor crimes, see Delaware v. Prouse, 440 U.S. 648, 663 (1979), where the Court states that a reasonable suspicion that a driver is driving with an expired license would justify a stop.

48. See United States v. Hensley, 469 U.S. 221 (1985).

49. See Florida v. Bostick, 501 U.S. 429 (1991); Schneckloth v. Bustamonte, 412 U.S. 218 (1973).

50. See Monkkonen, supra note 25 , at $166-67$ \& fig. 1 .

51. 399 U.S. $42(1970)$.

52. 500 U.S. $565(1991)$. 
requirement to homes and offices; elsewhere, police can almost always search and seize without advance permission from a magistrate. ${ }^{53}$ Unlike Terry, this change did not lower the substantive standard police have to meet to justify their actions. Even warrantless searches (Terry excepted) must be justified by probable cause. Instead, removing the warrant requirement from a category of searches makes those searches cheaper. Police need not fill out the application, wait for an available magistrate, and present their argument-they can search or seize, and take their chances at a suppression hearing later. When crime rises faster than police budgets, as it certainly did in the $1960 \mathrm{~s}$ and $1970 \mathrm{~s},{ }^{54}$ cheaper searches and seizures are not just adaptive. They're a necessity.

More recently, Fourth Amendment doctrine has moved in the opposite direction, following the steady and substantial decline in crime since the early 1990s. City of Chicago v. Morales invalidated a local gang-loitering ordinance, and thereby called into question dozens of state and local laws designed to give the police greater authority over young men in high-crime neighborhoods. ${ }^{55}$ Florida v. J.L. ruled that street stops based on uncorroborated tips are impermissible. ${ }^{56}$ City of Indianapolis v. Edmond held that roadblocks were likewise impermissible, unless undertaken for the purpose of protecting traffic safety ${ }^{57}$ Kyllo $v$. United States barred the use of thermal imaging equipment to "see" inside a home, save when authorized by a warrant. ${ }^{58}$ All these cases have been decided since 1999 , the

53. The key exception to the warrant requirement is the one for searches incident to arrest. See, e.g., United States v. Robinson, 414 U.S. 218 (1973). That doctrine allows the police to search the person and belongings of anyone who the police have probable cause to believe has committed a crimc. Since crimes can include such things as traffic offenses, see Atwater v. City of Lago Vista, 532 U.S. 318 (2001) (approving custodial arrest for the offense of driving without a seat belt), this power gives the police the ability to search, without a warrant, almost anyone in a vehicle, plus (depending on the stringency of local curfews and quality-of-life ordinances) a large portion of the pedestrian population to boot.

54. In 1960, the number of index crimes per 100,000 population was 1126; if one recalculates that number to take account of a change in measurement in 1972, the figure rises to 1614. See supra note 37 . In 1976, the number of index crimes per 100,000 population was 5266-either more than triple or more than quadruple the crime rate in 1960, depending on which figure one uses. Fed. BurEau of INVESTIGATION, UNIFORM CRIME REPORTS FOR THE UNITEd STATES1976, at 35 (1977) [hereinafter 1976 UNIFORM CRIME REPORTS]. The number of personnel in police departments-a good proxy for police budgets-grew much more slowly. In 1961 the number of full-time police department employees per 1000 population was 1.9. FED. BUREAU OF INVESTIGATION, UNIFORM CRIME REPORTS FOR THE UNITED STATES-1961, at 109 (I962). By 1976, that number had risen only to 2.5. 1976 UNIFORM CRIME REPORTS, supra, at 224 tbl.58.

55. 527 U1.S. 41 (1999). Chicago responded to Morales by enacting a new gang-loitering ordinance, see CHICAGO, ILL., MUNICIPAL CODE $\S 8-4-015$ (2000), but it may well be unconstitutional. See Jocelyn L. Santo, Note, Down on the Corner: An Analysis of Gang-Related Antiloitering Laws, 22 CARDOZO L. REv. 269, 271 (2000) (noting that "[v]ery few antiloitering ordinances have ... survived constitutional challenges"). For a defense of the new ordinance by one of its drafters, see Lawrence Rosenthal, Gang Loitering and Race, 91 J. CRIM. L. \& CRIMINOLOGY 99 (2000).

56. 529 U.S. $266(2000)$.

57. 531 U.S. $32(2000)$

58. 533 U.S. 27 (2001). 
same number of years from the beginning of the decade-long fall in crime rates as Terry was from the beginning of the crime spike of the 1960s. All raised plausible arguments of law enforcement need, arguments at least as strong as those that routinely prevailed in the $1980 \mathrm{~s}$. The ordinance at issue in Morales was an attempt to do something about gang violence in highcrime Chicago neighborhoods; J.L. involved a search for a weapon at a public bus stop (the kind of case where safety concerns have traditionally trumped all else); Edmond and Kyllo were classic war-on-drugs cases. Each of these decisions would have been surprising a decade earlier, and the combination of the four would have been unthinkable. ${ }^{59}$ That they are now thinkable owes more to changes in crime than to developments in law and legal theory. ${ }^{60}$

The larger pattern is clear. Crime fell in the 1940s and 1950s; Fourth Amendment rights expanded in the 1960s. Crime rose sharply in the 1960s; Fourth Amendment protection receded in the 1970s and 1980s. Crime fell again in the 1990s, and by the end of that decade Fourth Amendment rights were once again expanding. None of this is to say that Justices respond mechanically to changes in crime rates, or to anything else for that matter. Here as everywhere else, monocausal theories are implausible. But the pattern is strong enough, and alternative explanations seem weak enough, to justify the conclusion that crime rates have played a significant part in the ebb and flow of criminal procedure protections over the past two generations.

Judging from that pattern, one should ordinarily expect a substantial time lag, perhaps as much as a decade, between changes in crime and court

59. I do not wish to overstate the magnitude of the Court's shift toward more pro-defendant Fourth Amendment doctrine. These cases are by no means the equivalent of 1960 s decisions like Miranda and Mapp. And there have been other, more pro-police decisions during the same time period: Illinois v. Wardlow, 528 U.S. 119 (2000), permitted a Terry stop based largely on flight from a police officer in a high-crime neighborhood, and Atwater v. City of Lago Vista, 532 U.S. 318 (2001), allowed custodial arrests for nonjailable offenses. (It might be worth noting that both Wardlow and Atwater were 5-4 decisions-unlike Morales, Edmond, and J.L.) Still, even with these qualifications, the Court's Fourth Amendment decisions since 1999 seem strikingly different from its decisions in the $1970 \mathrm{~s}$ and 1980s; they are both more protective of suspects' interests and less deferential to claims of law enforcement need. Had the same set of decisions been handed down between 1989 and 1991 instead of between 1999 and 2001, I am confident that scholars and Court watchers would have been astonished.

60. Or to changes in personnel. Since 1990, four new Justices have taken office: David Souter replaced William Brennan in 1990; Clarence Thomas took Thurgood Marshall's seat in 1991; Ruth Bader Ginsburg replaced Byron White in 1993; and Stephen Breyer filled Harry Blackmun's chair in 1994. It seems implausible to claim that those changes would produce a Court that was more protective of criminal suspects' interests than the Court of the 1980s-Souter and Thomas are more pro-law-enforcement than the Justices they replaced, and Breyer's voting pattern in criminal cases is not much different from Blackmun's during the latter part of his tenure. Only the change from White to Ginsburg seems to favor suspects' interests. Yet the Court is more protective of those interests than it was in the 1980s. Put crudely, we have a Court whose personnel shifted to the right and whose criminal procedure decisions shifted to the left. Something other than the Justices' own ideologies scems to be at work. 
decisions. That would hardly be surprising. The Supreme Court may follow the election returns, as the old saw has it, but it would be surprising if the Court's decisions incorporated up-to-date information about large social trends. On the other hand, it would be similarly surprising if the Justices' thinking was uninfluenced by such trends over time. ${ }^{61}$ This raises a fair question about the one-day crime wave we saw on September 11. Will courts, including but not limited to the Supreme Court, react as they have to other spikes in serious crime? Will the reaction be similarly delayed?

The reaction will probably be the same, but the timing will not. September 11 represents the most immediately salient crime wave in the nation's history. It will not take years of scattered news reports to sink into the judicial consciousness; on the contrary, the sinking-in is already happening. ${ }^{62}$ And unlike other recent large-scale criminal events-e.g., the riots that followed the state-court acquittal of the officers who beat Rodney King - the murders on September 11 were of a sort that suggested an ongoing threat, something the legal system will be obliged to deal with for some time to come. Most famous crimes do not produce large-scale changes in behavior, and for a simple reason: The crimes do not appreciably raise anyone's risk of victimization. Sometimes there is a temporary public clamor-as when, a few years ago, a Maryland woman was dragged to her death while her car was being stolen, and state and federal governments scrambled to pass anticarjacking statutes. ${ }^{63}$ But the clamor quickly subsides; several years later, there is no reason to believe that the Maryland case significantly altered either police behavior or driving habits. The attacks on the Pentagon and the World Trade Center are different. They were carried out by an organization that still exists, and the leader of that organization has repeatedly announced his desire to kill Americans. Other organizations may have the same goal, and some national governments may be helping them. It is entirely rational to suppose that the

61. For a particularly insightful analysis of the ways in which the Supreme Court responds to the larger culture, see Michael J. Klarman, Rethinking the Civil Rights and Civil Liberties Revolutions, 82 VA. L. REV. I (1996). For the classic argument that the Court does indeed respond to larger social and political trends, see Robert A. Dahl, Decision-Making in a Democracy: The Supreme Court as a National Policy-Maker, 6 J. PUB. L. 279 (1957).

62. See, e.g., A Deliberate Strategy of Disruption; Massive, Secretive Detention Effort Aimed Mainly at Preventing More Terror, WASH. POST, Nov. 4, 2001, at A1 (noting courts' willingness to approve the widespread detention of terrorism suspects).

63. For a discussion of the Maryland case, see, for example, Don Terry, Carjacking: New Name for Old Crime, N.Y. TimEs, Dec. 9, 1992, at A18. The federal statute passed in response to this incident appears at 18 U.S.C. $\$ 2119$ (1994). For examples of state statutes, see FLA. STAT. ANN. ch. 812.133 (Harrison Supp. 2001); LA. REV. STAT. ANN. \$ 14:64.2 (LEXIS through 2001 Supp.); and N.J. STAT. ANN. § 2C:15-2 (West 1995). Louisiana went beyond criminalizing carjacking, specifically authorizing victims of carjackings to kill perpetrators. See Susan Michelle Gerling, Note, Louisiana's New "Kill the Carjacker" Statute: Self-Defense or Instant Injustice?, 55 WASH. U. J. URB. \& CONTEMP. L. 109 (1999). 
risk of mass murder is much higher than we perceived it to be on September $10,2001$.

The September 11 attacks already have produced large changes in behavior. Airplane travel is down. Security in all public spaces is dramatically tighter. It stands to reason that courts, like all other public institutions and like the public itself, will likewise see some changes in behavior-sooner rather than later.

At the Supreme Court, "sooner" may have arrived. United States $v$. Arviz $u^{64}$ arose out of a stop of a minivan with a family of five by a border patrol agent on a dirt road in southern Arizona. The agent suspected that the van might be carrying drugs, and the agent turned out to be right-once the van was stopped, the driver consented to a search that turned up more than a hundred pounds of marijuana. But at the time of the stop, the agent had only a few barely. suspicious facts to go on: The van was driving along a route sometimes used by smugglers to avoid highway checkpoints (but also used by local residents and vacationers), the van slowed down when the driver saw the border patrol car, the driver "appeared stiff and his posture very rigid," the children in the back of the van waved oddly to the agent (who was then following the van), the children's knees seemed to be propped up on something in the back of the van, and a registration check revealed that the van was registered to an address only a few blocks from the Mexican border "in an area notorious for alien and narcotics smuggling." ${ }^{65}$ A Ninth Circuit panel found no reasonable suspicion on these facts, noting specifically that several of the factors mentioned above deserved no weight because they did not suggest criminal behavior. ${ }^{66}$ The Supreme Court unanimously reversed in a notably dismissive opinion by the Chief Justice. No mention was made of terrorism, but in the oral argument in late November, the connection was clear. Speaking to Arvizu's lawyer, Justice O'Connor stated, "We live in perhaps a more dangerous age today than we did when this event took place," confessed concern that "the Ninth Circuit opinion seemed to be a little more rigid than ... common sense would dictate today," and noted that "it may become very important to us" to preserve the flexibility of the totality-of-the-circumstances test for reasonableness against the kind of rigidity she detected in the Ninth Circuit's approach. ${ }^{67}$ Arvizu would probably have come out the same way even before September 11. But probably not by the same vote, perhaps not with an opinion that so emphasized the value of deference to police

64. 122 S. Ct. 744 (2002).

65. Id. at $748-49$. The timing of the van's trip also coincided with a shift change by border patrol agents. $I d$. at 748 .

66. United States v. Arvizu, 232 F.3d 1241, 1248-49 (9th Cir. 2000), rev'd, 122 S. Ct. 744.

67. Justice O'Connor's statements are quoted in Linda Greenhouse, Court Rules on Police Searches of Motorists, N.Y. TIMES, Jan. 16, 2002, at A17. 
judgment, and surely not after an oral argument that made thinly veiled references to the need to fight terrorism.

Arvizu reveals something important about the mechanism by which the war on terrorism is likely to shape the law of criminal procedure. Courts often decide cases with an image in the background; debates about competing rules may boil down to choices among competing images. Because of September 11, the specter of the suicide bomber will play a much larger role in Fourth Amendment cases than it did before.

Part of that role involves legal changes that never happen: rules that, but for the terrorist threat, might have fallen by the wayside. Consider a pair of related Fourth Amendment doctrines, each of which has been the subject of a good deal of criticism of late. The first holds that police may arrest for any crime, not just crimes that pass some judicially defined threshold of seriousness; the leading case is Atwater $v$. City of Lago Vista. ${ }^{68}$ The second holds that searches and seizures are to be judged objectively - the officer's motive for the search is irrelevant. Here the key decision is Whren v. United States. ${ }^{69}$ Taken together, Atwater and Whren allow police officers to use trivial "crimes" like minor traffic violations as an excuse to detain and search people whom they suspect of more serious offenses. In legal terms, the debate about racial profiling on the highways is largely a debate about the merits of these two rules. With them, officers can select a few speedlimit violators out of the large universe of such violators (all drivers speed) and stop them in order to search for drugs - and that course of action is perfectly legal. Without this pair of rules, such behavior would be a great deal harder to justify.

Before September 11, one might plausibly have predicted that Atwater and Whren would not long survive, at least not in their current form. Whren, decided five years ago, was unanimous; by the time the related issue in Atwater was posed last year, the Court split 5-4. The reason for the shift is not hard to discern: The Atwater dissent noted the specter of racial profiling hanging in the background, ${ }^{70}$ and the Atwater majority was careful to premise its holding on the absence of large-scale strategic behavior of the sort described in the preceding paragraph. ${ }^{11}$ Whatever the Court might have done on this score, it seemed certain that its decisions were in some basic sense going to be "about" profiling and pretextual traffic stops.

As Justice O'Connor's comments in the Arvizu oral argument suggest, ${ }^{72}$ after September 11 those decisions are likely to be about something else. A

68. 532 U.S. $318(2001)$.

69. 517 U.S. 806 (1996).

70. See 532 U.S. at 372 (O'Connor, J., dissenting) ("IA]s the recent debate over racial profiling demonstrates all too clearly, a relatively minor traffic infraction may often serve as an excuse for stopping and harassing an individual.").

71. See id. at 353 (majority opinion) (noting the "dearth of horribles demanding redress").

72. See supra text accompanying note 67 . 
different specter hangs in the air: the suspected terrorist who has violated some traffic rule or whose immigration paperwork is not quite right. A recent case in a small town near Boston makes the point. ${ }^{73}$ The police stopped the driver of a brown Honda outside a large gas storage facility at 10:30 p.m. The driver had an invalid Lebanese driver's license, no passport, and a credit card with a different name from the one on his license. When asked what he was doing in the area, the driver said he was about to interview for a job; needless to say, no interviews were occurring at that hour. Before the attacks on New York and Washington, the driver would have been released-indeed, he never would have been detained, because he would not have been questioned. As it happened, he was detained on the traffic charge while police tried to sort out what, if anything, had almost happened at the storage facility. That is the scenario that will hang in the background of the next Whren or Atwater.

The same phenomenon-judicial concern for the need to fight terrorism, applied to cases that may have nothing to do with terrorism-is likely to produce legal change, not just prevent changes that otherwise might have happened. The question is where the changes are likely to be. The answer is, in places where the law limits powers that police are likely to value more highly after September 11 than before.

One might wonder whether this dynamic will be limited to federal cases. After all, the war on terrorism-unlike the war on drugs before it-is primarily the responsibility of the federal government. That allocation of authority distinguishes the September 11 attacks from more ordinary crime waves, in which local police bear primary responsibility and federal agents are mere backstops. One could imagine that distinction having a large effect on how judges react to this new, or newly salient, crime problem. When crime goes up across the board, local police feel the pressure, the cost of legal rules that restrain the police rises, and courts feel pressure to relax those rules. But if federal agents are solely responsible for dealing with this crime wave, courts may not feel the same sort of pressure; the legal reaction might be both modest and specific to federal law. Perhaps we will see not a change of direction in the broader law of search and seizure, but rather divergence between the standards to which federal agents are held and the rules that bind local police. ${ }^{74}$

73. The incident was briefly noted in the Boston Globe. Motorist Arrested near LNG Terminal, BOSTON GLOBE, Oct. 30, 2001, at B2. The details that follow arc taken from that news report and from the police report. See Police Officer's Formal Report, Case No. 206672, Everett, Mass., Police Dep't (Oct. 23, 2001) (on file with author).

74. That would be an ironic twist. Historically, the law governing federal policing was stricter than the law governing local police, because federal agents alone were bound by the Bill of Rights. Some academic comment seeks to recreate that state of affairs. See George C. Thomas III, When Constitutional Worlds Collide: Resurrecting the Framers' Bill of Rights and Criminal 
That scenario is possible, but not likely. Local police have already been affected by the terrorist attacks, and powerfully so. The FBI may have primary responsibility for investigating allegations, but that agency lacks the manpower to guard public places. Local police must do so. The manpower they use in that task must come from somewhere, and the most obvious "somewhere" is street policing. It hardly comes as a surprise, then, to see local police departments complaining of the major drain on their resources from antiterrorism work. ${ }^{75}$ It will be hard to increase those resources in a recession. At least in the near term, the more likely response is a combination of greater efficiency in the investigation of other crimes and a reduction in the level of policing of those crimes, in order to free up more manpower for homeland security. One of the ways to achieve greater efficiency is to relax legal restrictions. In short, we are likely to see the same kind of pressure for legal change that we see in times of across-theboard rises in crime. (Not to mention that we may yet experience an acrossthe-board rise in crime as a consequence of the September 11 attacks. $)^{76}$ Courts are likely to respond to that pressure in the same manner-by giving police more power. The fact of such a response is both proper and, at least given recent practice, normal. The important question is the nature of the response.

\section{OFFERING GREATER POWER, REQUIRING GREATER RESTRAINT}

Like the war on drugs before it, the war on terrorism is likely to leave us with a different law of criminal procedure than we had before. Though some of the differences will be limited to antiterrorism police work, most will be general; they will affect the way local police deal with ordinary crimes. The mechanism is simple. The federal agents who fight terrorists value some law enforcement powers especially highly, because those powers are particularly useful weapons in that fight. Courts will be-and, if the argument in the preceding Part is right, should be-quick to grant the police considerable leeway in how they use those weapons, in order not to impede antiterrorism policing. The weapons themselves, though, will be used not only by FBI agents trying to stop would-be suicide bombers, but also by local police attacking robberies and drug deals.

It is not hard to imagine where we will see these expanded police powers. There are three major areas where law enforcers are likely to value their authority more highly after September 11 than before. First is

Procedure, $100 \mathrm{MICH}$. L. REV. 145 (2001). So far as I know, no one has argued that federal agents should be less regulated than local police.

75. This has been a theme of the New York Times's reporting on the aftermath of September 11. See, e.g., sources cited supra note 5.

76. See supra note 6 and accompanying text. 
profiling. The terrorist attacks on Washington and New York were committed by young or early-middle-aged men of Middle Eastern origin. Antiterrorism law enforcement is not going to target people in those categories exclusively (notice the news reports at the height of last fall's anthrax scare suggesting its source might be domestic right-wing groups ${ }^{77}$ ), but young men of Middle Eastern origin are clearly going to receive more police attention than the rest of the population. Equally important, judges are going to be slower to disapprove other sorts of profiling than they were before September 11, lest they interfere with efforts to catch suicide bombers.

Second is secret information-gathering. Much of the evidence-gathering the police do is out in the open, or nearly so. Other kinds of investigation, though, are secret by design. So-called sneak-and-peek warrants authorize searches of dwellings whose occupants will not know they have been searched. Wiretaps work precisely because participants in conversations on tapped phones do not know they are being monitored. The same is true of searches conducted over the Internet. Recently enacted antiterrorism legislation expanded the FBI's authority to conduct each of these types of secret searches. ${ }^{78}$ That is no surprise. The government needs to do a great deal of preliminary investigation in these cases merely to identify suspects, and the investigation must be secret, for the suspects are likely to have the resources and the ability either to go into hiding or to flee the country.

Third is interrogation. Antiterrorism work is mostly about the business of preventing future crimes, not solving past ones. This is crime prevention of a different sort than we see discussed in policing circles. Street crime can sometimes be avoided by establishing a police presence in the right places at the right times ${ }^{79}$ but terrorist attacks are not preventable by such means. They are too geographically dispersed, and the attackers are too sophisticated-this is not opportunistic crime in a few "hot spots," but something both less visible and less easily deterred. To find and prevent it, the police need information. In most criminal networks, such information is best obtained through informants and undercover agents. No doubt some of that will happen here as well, but we should not be optimistic. Only a very small group of people could penetrate the relevant terrorist networks (or be recruited from within such networks), and finding them is a hard, time-

77. E.g., Bob Woodward \& Dan Eggen, FBI and CIA Suspect Domestic Extremists; Officials Doubt Any Links to Bin Laden, WASH. POST, Oct. 27, 2001, at A1.

78. USA PATRIOT Act, supra note $2, \S \S 206,213,216,115$ Stat. at 282, 285-86, 288-90.

79. There is a large debate about just how and how well that process works. Compare George L. Kelling \& Catherine M. Coles, Fixing Broken Windows: Restoring Order AND REDUCING CRIME IN OUR COMMUNities (1996), with BERNARD E. HARCOURT, ILluSION OF ORDER: THE FALSE PROMISE OF BROKEN WINDOWS POLICING (2001). 
consuming process. ${ }^{80}$ The best source of information is likely to be the suspects themselves. If these suspects decide not to talk, agents are likely to want to induce them to change their minds.

These are the three major pressure points-profiling, secret searches, and interrogation. These are the most important areas where the government will seek, and probably get, more power as a consequence of its need to catch terrorists and prevent terrorism. And this power will not be limited to terrorism investigations, any more than Atwater and Whren are likely to survive but apply only to would-be bombers of gas storage facilities. In each case, the pressure on the law comes from terrorism, but the relevant power extends to local police investigating local crimes. Although the specter of terrorism is likely to drive legal change in these three areas-just as the specter of an out-of-control crack market drove legal change a dozen years ago-the largest consequences will be felt in more ordinary cases. If there are ways to respond to the pressure while preserving or even enhancing individual freedom, we need to identify them.

The Sections that follow seek to begin that work of identification. The results all involve a kind of regulatory swap: greater police authority along one axis coupled with greater restriction along another. In evaluating these proposals, it is important not to lose sight of the bigger picture. The law should and will adapt to new circumstances like the need to fight terrorism. As it does so, we should think carefully about how legal change affects more ordinary sorts of policing. There is a real opportunity here: Given the many deficiencies of the way we police the police now, it is possible to craft reforms that would be adaptive in the near term and productive in the longer term.

\section{A. Profiling}

Racial or ethnic profiling - the selection of targets of police attention based in part on race or ethnicity - was a large issue in legal and policing circles before September 11. It is an even larger issue now. ${ }^{81}$ Solving this particular problem is, to say the least, hard. The problem involves discriminatory purpose in a setting in which purpose is always mixed: Few police officers are in the habit of stopping motorists or pedestrians solely because they are black. Legal regulation of mixed-motive behavior is always a complicated task, as even a glance at the law of employment

80. See Philip B. Heymann, Terrorism and America 25-26, $130-31$ (1998). As Heymann notes, these conditions hold for foreign and domestic antiterrorism woli alike.

81. For an excellent discussion of the ways in which the fight against terrorism has, and has not, changed the debate about profiling, see Samuel R. Gross \& Debra Livingston, Racial Profiling Under Attack, 102 COLUM. L. REV. (forthcoming 2002) (manuscript on file with author). 
discrimination would suggest. There are difficult remedial questions as well. If police in a given jurisdiction disproportionately stop and arrest Latinos, is the solution to invalidate those stops and arrests? If so, which ones? Or is it to command that the police arrest more non-Latinos? If so, how? To the extent the relevant selection is not of individual suspects but of neighborhoods, the problem quickly becomes unmanageable. No court is in a position to evaluate decisions to allocate officers to some neighborhoods rather than others. The same is probably true of decisions to use different police tactics in different neighborhoods. Those differences are inevitable, given that crime differs across neighborhoods. Yet those differences naturally produce racial tilts in the selection of suspects and arrestees, given the high level of racial segregation in urban neighborhoods.

Yet if solving the profiling problem is impossible, mitigating it is well within the law's capability. The following Subsections suggest two legal changes that would cabin profiling's effects, and argue that cabining effects is the best that can be done in this area.

\section{Searching and Seizing Groups}

The first change has little to do with fighting terrorism. At the same time, it may be the most productive change the law could make in terms of simultaneously increasing both police authority and public welfare. The change concerns the legal treatment of searches and seizures of groups. (By "groups," I mean classes of people defined by place and time-everyone who happens to be driving past a particular point on a particular road at a particular time, everyone who occupies a given building or public space at a given time, and so forth. I do not mean classes of people defined by characteristics such as race, sex, alienage, or occupation.)

For the most part, police officers want to search, seize, and question individuals, not groups. This desire is natural: It is cheaper to stop one person than to stop fifty. Sometimes, however, there is no alternative to stopping the fifty. After September 11, no airport security team would be willing to question only some passengers; the risks are such that all must be questioned, at least briefly. Even when group searches and seizures are not essential, as they are thought to be in airports today, they may be efficient. A number of communities have found roving roadblocks, with the police stopping every car and questioning every driver in a given location, to be an effective means of deterring drunk drivers. Indianapolis's brief experience with roadblocks as a drug enforcement tool evidences its efficiency in that setting as well. ${ }^{82}$ As these examples suggest, there are sometimes good

82. See City of Indianapolis v. Edmond, 531 U.S. 32, 34-35 (2000) (noting that about five percent of stopped cars in drug checkpoints led to drug arrests and another four percent led to 
reasons for the police to target groups rather than individuals, even though most of the time police preferences are likely to run in the other direction.

Current Fourth Amendment law discourages group seizures. With a few limited exceptions-airport security, drunk driving roadblocks, border patrol, and little else-the law holds that police may not seize groups of people unless each individual seizure is justified. $^{83}$ Aggregate justifications - no one person is reasonably suspected, but the odds are high that some members of the group are criminals-do not suffice ${ }^{84}$ Thus, were the police to set up a roadblock in order to catch not drunk drivers but drug dealers, not knowing which among the cars stopped were carrying drugs, any evidence found would be suppressed, and the police might well be liable for damages to those stopped. ${ }^{85}$

So the Supreme Court decided just last Term, in City of Indianapolis $v$. Edmond: ${ }^{86}$ The police act on individuals, not groups, and so legal justifications for police action must be tied to individual targets, not to the groups to which the targets belong. Though the Edmond Court applied that norm, it did not explain or defend it; the norm was treated as too obvious to merit extended discussion.

Yet the norm is perverse. Group searches and seizures, unlike individual ones, are largely self-regulating. If Fourth Amendment law gave police free rein to stop large groups of motorists or pedestrians for brief questioning, the result would not be an orgy of roadblocks and street sweeps, for police have reasons other than the law to use such tactics with care. Then too, retail searches and seizures are likely to cause more harm than the wholesale kind. This would be true even in a monoracial society, but it is all the more true in a racially divided one, for discriminatory policing is much harder to combat when the police deal with individuals than when they deal with groups.

Consider why constitutional regulation of searches and seizures is necessary in the first place. Police are in the business of imposing costs on suspects. Stops, frisks, arrests, detentions, questioning - these things are generally unpleasant and can be seriously harmful. The benefits of this sort of activity are diffused among the local population. The costs, at least the

arrests for other offenses). By comparison, the success rate in the drunk driving roadblocks at issue in Michigan Department of State Police v. Sitz, 496 U.S. 444 (1990), was less than one percent. See id. at 448.

83. The leading case on the legality (and mostly illegality) of group seizures is Edmond, 531 U.S. 32, which invalidated roadblocks used to catch drug offenders. On roadblocks as a tool for catching drunk drivers, see Sitz, 496 U.S. 444 . On roadblocks as a border control device, see United States v. Martinez-Fuerte, 428 U.S. 543 (1976).

84. See, e.g., Ybarra v. Illinois, 444 U.S. 85 (1979).

85. Edmond was a civil suit for injunctive relief. 531 U.S. at 36 . After that decision, such seizures satisfy the "clear illegality" standard that qualified immunity doctrine applies to constitutional damages litigation. See Anderson v. Creighton, 483 U.S. 635 (1987).

86. 531 U.S. 32 . 
nonmonetary sort (which are more severe than the monetary costs), are concentrated; they are felt primarily by those whom the police target. Anytime the government does something that has concentrated costs but diffused benefits, there is a danger that it will do too much-harming one voter to please ten is generally thought to be a good deal from the point of view of politically accountable decisionmakers. ${ }^{87}$ That is the theory behind the Takings Clause, which requires compensation as a condition of seizing one person's property for the benefit of the larger public. ${ }^{88}$ Law enforcement presents what looks like a recurring takings problem-only the problem is not so easily solved. A compensation requirement for searches and seizures is obviously implausible (try to imagine giving every arrestee a government check). Yet absent something like mandatory compensation, there is good reason to fear that the police will not take sufficient account of the interests of the suspects they target. ${ }^{89}$ That is the strongest case for constitutional regulation of law enforcement. Some kind of regulation is needed, and political checks will not do the job, given politicians' natural tendency to worry too little about those who bear the nonmonetary cost of police work.

Notice that the argument concerns police searches and seizures of individuals. When the police stop large groups of people, the story is quite different. Law enforcement's costs are spread more broadly; the effect is to convert searches and seizures from takings, burdening only isolated

87. Aficionados of public choice theory will see the statement in the text as backward. According to that theory, it is precisely when costs are concentrated that interest groups form to combat imposition of those costs. Thus, the real danger is not concentrated costs coupled with diffused bencfits, but concentrated benefits and diffused costs.

That may often be true. But the need for something like the Takings Clause shows that it is not always true. If the cost-bearers are sufficiently few-e.g., the single landowner whose land is seized for a new airport-or powerless, or if there are barriers to their coalescing to fight the relevant government action, the government is likely to find it tempting to concentrate costs. For good discussions of these points, see Einer R. Elhauge, Does Interest Group Theory Justify More Intrusive Judicial Review?, 101 YALE L.J. 31 (1991); Daniel A. Farber, Public Choice and Just Compensation, 9 Const. CoMment. 279 (1992); and Daryl Levinson, Making Government Pay: Markets, Politics, and the Allocation of Constitutional Costs, 67 U. CHI. L. REV. 345 (2000). Those who bear the nonmonetary cost of policing tend to fall into the latter two categories. Criminal suspects are not a notably powerful voting bloc, nor are young males in poor urban neighborhoods. Also, the targets of police attention do not know who they are until they have been targeted-and even then, they do not know who else has been targeted. These are large obstacles to interest-group formation.

88. There is an enormous literature on the Takings Clause. Much of that literature is devoted to "regulatory takings," cases in which government regulation has reduced the value of private property without actually expropriating it. Good discussions of the basic idea of the Takings Clause are less common. For examples in addition to the sources cited in the preceding footnote, see Saul Levmore, Takings, Torts, and Special Interests, 77 VA. L. REV. 1333 (1991); and Frank I. Michelman, Property, Utility, and Fairness; Comments on the Ethical Foundations of ". Iust Compensation" Law, 80 HARV. L. REV. 1165 (1967).

89. Even with a compensation requirement, police may not take sufficient account of suspects' interests, since government institutions may not respond to damages liability the way profit-maximizing private institutions do. See Levinson, supra note 87. 
individuals, into taxes, burdening classes of people. And when groups are searched or seized, the burdens are more visible-a larger slice of the population can see and hear them. These differences mean that political checks are much more likely to function. If the police treat individual arrestees badly, there may be no pressure brought to bear to treat them well, but if they treat groups of citizens badly, the bad treatment is likely to have political costs. To put it another way, spreading the cost of policing through a larger slice of the population (which is what things like roadblocks and security checkpoints do) reduces the odds of voters demanding harsh and intrusive police tactics secure in the knowledge that those tactics will be applied only to others.

The point is not that searching and seizing groups is always better than the alternatives. Usually, it isn't. Police work generally involves differentiating people, not lumping them together, and the law neither can nor should change that. Rather, the point is that with across-the-board search procedures-police work that taxes instead of takes-those who enforce the law tend to take account of both the benefits and the costs of their tactics. With individual searches, the costs tend to be externalized. It follows that when police officers want to deal with suspects wholesale rather than retail, the law should encourage them to do so. In terms of regulatory strategy, group searches and seizures are an opportunity, not a problem.

This would be true even if group stops entailed the same kinds of harms as individual stops. But they don't. When a single driver is pulled over, the experience is different and worse than if the same driver were stopped for the same period of time along with every other driver passing through a checkpoint. Sherry Colb calls the difference "targeting harm." ${ }^{90}$ While it may be impossible to define the harm with precision, it plainly exists. When the police stop fifty people, they do not cause fifty times the injury inflicted when they stop one. On the contrary, they are likely to cause a small fraction of the injury inflicted by stopping the same fifty people one by one.

Thus far, I have said nothing about the composition of the groups stopped. There is always reason to worry about the potential for discrimination in police work. One might reasonably wonder whether group seizures are a problem on that score. At least with respect to roadblocks and checkpoints-the kinds of group seizures the courts have dealt with most often-the answer is probably no. In many (most?) places in the United States, pedestrian traffic is quite segregated but vehicular traffic is not. ${ }^{91}$ If

90. Sherry F. Colb, Innocence, Privacy, and Targeting in Fourth Amendment Jurisprudence, 96 COLUM. L. REV. 1456, 1464 (1996).

91. This follows naturally from the degree of residential segregation in the United States. See, e.g., Douglas S. Massey \& NanCy A. Denton, American APartheid: Segregation and THE MAKING OF THE UNDERCLASS (1993). 
the New Jersey state police had stopped, say, every tenth car that was speeding (thereby creating the equivalent of a roadblock without stopping all traffic) instead of selecting the cars troopers wanted to stop, the racial disproportion found in John Lamberth's famous study of Turnpike stops ${ }^{92}$ might have disappeared. ${ }^{93}$ At the least, group seizures in that kind of setting-seizures of integrated populations-ought to be permitted with or without individualized suspicion.

The same conclusion may hold even when the groups are not integrated. Suppose the police officers investigating drug trafficking in a poor African-American neighborhood have to choose between two tactics-street sweeps, with everyone in the vicinity of a supposed drug market stopped and questioned, or targeted individual stops. Both tactics may involve a species of discrimination, since in white neighborhoods the tactics may be different, and the number and severity of the stops smaller. But the sweeps have a large advantage: transparency. The more people who see a police raid and feel its effects, the more people who are in a position to complain if police tactics are needlessly harsh, and in a position to counter false police testimony if the need arises. (How likely is it that Rodney King would have become a cause célèbre without the famous videotape? How likely is it that Officer Koon and his friends would have behaved so brutally had they been dealing with a dozen citizens instead of three? ${ }^{94}$ Discriminatory street sweeps and discriminatory street stops are both discriminatory, but the first kind of discrimination is more likely to occasion public complaint, and hence less likely to involve the kind of behavior that prompts complaint, than the second. The idea is much the same as the one behind requiring public trials: Visibility is a powerful regulatory tool. The ban on group seizures gets that idea backward.

This ban would be a bad thing at any time, but it is a particularly bad thing when the level of police surveillance in public places is kicking up a few notches. Different police tactics are, from the point of view of the police, substitutes for one another. Make one tactic cheaper relative to the other, and police will shift at the margin from the more expensive tactic to

92. See David A. Harris, The Stories, the Statistics, and the Law: Why "Driving While Black" Matters, 84 MINN. L. REV. 265, $277-80$ (1999) (citing Report of Dr. John Lamberth, Plaintiff's Expert, Revised Statistical Analysis of the Incidence of Police Stops and Arrests of Black Drivers/Travelers on the New Jersey Tumpike Between Exits or Interchanges 1 and 3 from the Years 1988 Through 1991, at 2, State v. Soto, 734 A.2d 350 (N.J. Super. Ct. Law Div. 1996) (No. 88-07-00492)).

93. If the troopers stopped only cars driving at least fifteen milcs per hour over the speed limit, some racial disproportion would have remained-a recent study found black drivers substantially more likely to drive at very high speeds than white drivers. See David Kocieniewski, Study Suggests Racial Gap in Speeding in New Jersey, N.Y. TIMES, Mar. 21, 2002, at B1 (reporting on the study).

94. King was apprehended after a high-speed car chase in a car with two other passengers. Koon v. United States, 518 U.S. 81, 85-86 (1996). 
the cheaper one. Police are regularly in the position of choosing between dealing with people individually or in groups; as pressure builds in the wake of the terrorist attacks, those choices are likely to be ever more frequent. Right now, the law makes the second option presumptively illegal, and hence expensive relative to the first. ${ }^{95}$ The result is to increase the targeting of individuals. Fewer roadblocks mean more individual traffic stops; fewer street sweeps mean more individual Terry stops. And it is the individual stops that carry the greatest risks of both harm to the target and discrimination by the police. It is also the individual stops that are hardest for the citizenry to monitor.

At least that is true when the searches and seizures are themselves limited. Arrests, extended detentions, house searches, strip searches-all these require probable cause now, and this state of affairs should continue. ${ }^{96}$ What I propose here is no more than what was at stake in Edmond. The roadblock in Edmond involved brief detentions in public, along with a few minutes of police questioning and, sometimes, a brief search of a suspect's outer clothing and the inside of her car. These are the usual incidents of a Terry stop and frisk. They should be within the scope of police authority, not only when the police have reasonable suspicion of both a crime and the presence of a weapon, but also when the people seized and searched qualify as a group. ${ }^{97}$

If individual stops were regulated more severely, the argument for tolerating group stops would be weaker. But in a world that grants police the authority to stop any motorist, at any time, for any reason-that is the

95. I say "expensive" rather than "forbidden" because the police are likely to see the legal penalties that apply to Fourth Amendment violations as prices rather than sanctions. For the classic discussion of the difference, see Robert Cooter, Prices and Sanctions, 84 COLUM. L. Rev. 1523 (1984).

96. Intrusive searches and seizures like those mentioned in the text tend to require removal of the suspects from public spaces. Once suspects are taken to the police station or otherwise removed from the places where they were first stopped, the public can no longer function as a watchdog, and the regulatory advantages of group searches and seizures diminish substantially.

97. One might wonder whether courts could feasibly define "group" for these purposes. The three suspects stopped in Terry v. Ohio, 392 U.S. 1, 5-7 (1968), plainly should not qualify, while the dozens of people stopped at a typical roadblock plainly should. The question is where to draw the line between Terry and the roadblock, and the answer is not obvious.

The problem sounds difficult in the abstract, but it would likely be a small problem in practice. After all, for ten years-the time between the Court's decisions in Michigan Department of State Police v. Sitz, 496 U.S. 444 (1990), and Edmond-group seizures appeared generally legal. Sitz found that, despite a one percent success rate, see 496 U.S. at 469 , the benefits of the roadblock program at issue outweighed its costs. The same argument could easily be made in favor of drug checkpoints or street sweeps in high-crime neighborhoods. Thus, group definition should have been an issue throughout the 1990s. Yet it appears to have generated no litigation. The likely reason is that the line draws itself. If the police stop everyone at a given place and time (that much should certainly be part of the definition of groups), they will rarely stop only three or four people. That is, most cases would fall pretty clearly on one side of the line or the other. Thus, it would probably suffice for courts to say "we know groups when we see them," and leave it at that. 
upshot of the approval of pretextual stops in Whren v. United States ${ }^{98}$ barring roadblocks seems somewhere in the vicinity of crazy, since it steers the police away from a less harmful tactic and toward a more harmful one. And in a world where the law of street stops and the law of consent searches combine to give police almost as much power to stop pedestrians as to pull over cars, a ban on street sweeps is perverse for the same reason. Some marginal substitution of group searches for individual ones is very likely to raise the quality of police treatment of suspects even as it raises the ability of the political process (instead of the courts) to regulate policing. These are real social gains.

Some such substitution would also make policing more democratic, by better spreading the pain that inevitably attends law enforcement. Today, the public tolerates long lines at airport security stations. As it should: All air travelers benefit from heightened security; it is only fair that all should pay some price for that benefit. We should welcome the opportunity to apply that logic more broadly.

\section{Regulating the Manner of Individual Searches and Seizures}

Whatever the law does with respect to group seizures, police will continue to seize mostly individuals. Here, the prevailing regulatory strategy can only be called strange. As a general matter, Fourth Amendment doctrine regulates (lightly) the question whether a suspect can be searched or seized, but not how. Terry doctrine holds that an officer may seize a suspect when the officer has reasonable, articulable grounds for believing the suspect might have committed or might be about to commit a crime..$^{99} \mathrm{~A}$ frisk of the suspect's outer clothing is permitted if the officer has reasonable grounds for suspecting the presence of a weapon. ${ }^{100}$ The frisk doctrine sounds like a substantial restriction on how searches are carried out, but this impression is misleading. In practice, anything that, according to the officer's testimony, feels like it might contain a weapon justifies forcibly emptying the suspect's pockets. That category includes just about anything. ${ }^{101}$ (Keep in mind that the weapons need not be guns, and that

98. 517 U.S. 806 (1996). Because almost everyone violates one traffic regulation or another, the requirement of reasonable suspicion or probable cause offers no restriction on police officers' ability to stop drivers. A ban on pretext stops would at least limit stops designed to investigate something other than a traffic violation-surely a sizeable proportion of vehicle stops, though no one knows precisely how large the proportion is. But Whren explicitly rejects such a ban. Id. at $812-13$.

99. E.g., United States v. Hensley, 469 U.S. 221 (1985).

100. Terry, 392 U.S. at 27.

101. 4 WAYNE R. LAFAVE, SEARCh AND SEIZURE \$ 9.5(c), at 279 (3d ed. 1996) (" [C]ourts have upheld as proper searches [that] turned up ... objects ... such as a pocket tape recorder, a pipe, a pair of pliers, cigarette lighter, several keys taped together, a metal money clip full of money, tightly wrapped bags of crack cocaine, or a prescription bottle." (footnotes omitted)). 
almost any kind of container could house a small knife or razor blade.) The upshot is that a wide range of police behavior, from fairly polite to fairly brutal, can satisfy Terry. Which gives police officers an incentive to limit whom they stop and frisk but no incentive to moderate their methods.

In theory, consent search doctrine and its twin, the legal definition of "seizures," might change that state of affairs for the better. Police-citizen encounters are deemed consensual, and hence not subject to any Fourth Amendment regulation, when the police behavior is not unduly coercive. ${ }^{102}$ Searches are consensual if suspects voluntarily authorize them. ${ }^{103}$ These doctrines would seem to give the police an incentive to be polite and nonthreatening; by doing so, they can avoid having to meet Terry's requirements.

It does not work that way in practice. First, Terry's requirements are easily met. Reasonable suspicion may mean little more than being a young man in a high-crime neighborhood on a street corner where drug deals are thoight to happen. ${ }^{104}$ Save when the police are stopping everyone at the scene of a crime (see the preceding Subsection), the police are likely to have enough information to justify almost any stop they want to undertake. Second, consent search doctrine applies, generously, even when the suspect has already been seized. ${ }^{105}$ An officer can stop and frisk a suspect, or even put him under arrest, and only then ask if the suspect will permit a search of his car. Under those circumstances, the answer is very likely to be "yes," and that "yes" is enough to authorize the search. This substantially diminishes the reward for avoiding seizures.

In short, the law places only the lightest of limits on whether a suspect can be seized, and nearly no limits at all on how. Consider two narratives taken from the state Attorney General's report on street stops in New York City. Here is the first:

102. The nominal definition of "seizure" is this: One is seized when a reasonable person in one's shoes would not feel free to terminate the encounter. See Florida v. Bostick, 501 U.S. 429 , 438 (1991); United States v. Mendenhall, 446 U.S. 544 (1980). If courts took that definition seriously, almost all police-citizen encounters would be seizures, since hardly anyone feels free to walk away from a police officer without the officer's permission. The actual (though unarticulated) definition is more like this: One is seized when a police officer behaves with a higher level of coercion than is ordinary and reasonable in a brief street encounter. For a survey of the cases, see 4 LAFAVE, supra note 101, \$ 9.3 (3d ed. 1996 \& Supp. 2002).

103. See Schneckloth v. Bustamontc, 412 U.S. 218 (1973).

104. Cf. Illinois v. Wardlow, 528 U.S. 119 (2000). The central issue in Wardlow was whether the suspect's flight gave rise to reasonable suspicion. But the Court, in finding for the state, emphasized Wardlow's presence in "an area known for heavy narcotics trafficking"; indeed, the Chief Justice noted that fact and used some form of that phrase three times in his brief opinion for the Court. Id. at 121,124 . The Court thus seemed to say that even without Wardlow's flight, the police were close to having reasonable suspicion.

105. See Ohio v. Robinette, 519 U.S. 33 (1996). 
John Reyes is a 22-year-old Hispanic male who resides in East Harlem....

... Mr. Reyes left [his workplace] at approximately 12:30 a.m. He arrived at his building at approximately 1:00 a.m. Mr. Reyes entered his apartment building, walked to the elevator bank, and was waiting for the elevator when four or five men appeared. "I felt like they came from no where. Although they were not in uniform, a few of the men had their badges on, so I knew that they were police officers." The police officers questioned him about where he was coming from. They frisked him and searched his bag. In the midst of a search of his bag, the officers asked Mr. Reyes if he lived in the building. He told them that he did.

"Once the police officers seemed satisfied that I was not in possession of any contraband, and that they were going to let me go on my way, I felt comfortable to ask them what was going on.... They told me that they had received a report that shots had been fired, and that I fit the description of the perpetrator. They didn't give me any more details." 106

And the second:

Jean Davis is a 54-year-old African American woman who resides in Brooklyn. Davis works as a home health aide for elderly persons. Her encounter with the NYPD occurred . . a at about 10:30 p.m.

That evening, Ms. Davis had worked as an aide at a client's home five blocks away from her house. At the end of her shift, she left the client's home and walked on foot toward her house. Two blocks from her home, she noticed a white man walking in the street. Ms. Davis thought it was strange to see a white person in her predomin[antly] black neighborhood. Since there recently had been reports of crimes in the area, Ms. Davis quickened her pace. She was almost at her home when the man suddenly approached her from behind and grabbed her around her neck. "I screamed. . . I thought I was being attacked, so I screamed. I was only a few houses away from where I lived, and I thought I could scream loud enough that my son would hear me, and come to my rescue."

"The man told me to be quiet because he was a police officer, but I really didn't know whether to believe him because he did not

106. OfFICE OF THE ATtORNEY GEN. OF THE STATE OF N.Y., THE NEW YORK CiTy POLICE DEPARTMENT'S "STOP \& FRISK" PRACTICES: A REPORT TO THE PEOPLE OF THE STATE OF NEW YORK 76-77 (1999) [hereinafter STOP \& FRISK REPORT] (third ellipsis in original). 
show me any identification... [T]he next thing I knew, the man was forcing me to walk down the street, back towards the direction he came from. He pulled me down the street towards a car. As we got closer to the car, I saw another man get out of it. The man who was holding me forced me to put my hands on the hood of the car, and patted down the sides of my body and legs."

By this time, Ms. Davis knew that the two men were police officers. Her original fear began to subside as her anger grew. Ms. Davis stated that the officer then conducted a full search of her person, removing the contents of her jacket pockets, shaking her pants legs, removing the baseball hat she was wearing, and shaking that out as well.

At this point, Ms. Davis asked the officers for an explanation. One officer explained that [they] had gotten a call informing them that someone had purchased drugs in the area, and that she fit the description of the alleged purchaser. The officer was not specific about the description. The officer then walked up and down the street looking for drugs. Ms. Davis, now suspicious of the officers and irritated by her continuing detention, feared that an officer might plant drugs on her to cover up his mistake. Ultimately, the officer told Ms. Davis that she was free to go. ${ }^{107}$

Legally, these two encounters are quite similar. In both cases the police had a description of an offender and a suspect who matched it, satisfying the reasonable suspicion standard. In both cases, the police appear to have searched more aggressively than Terry doctrine contemplates. (Notice the word "contraband" in the description of the first encounter.) But these searches could plausibly, maybe easily, have passed muster in a suppression hearing. In Mr. Reyes's case, the police had a report of a shooting, which gave them reason to fear that a weapon might be in the bag. In Ms. Davis's case, the officers could have testified that the drug trade in the relevant neighborhood was associated with a lot of violence and that they didn't know what might be hidden in, say, her baseball cap.

Functionally, though, the second encounter seems much worse than the first. With Mr. Reyes, the police acted quickly and proportionately (they were investigating a shooting), explained their behavior satisfactorily (though it would have helped had the explanation come before the suspect asked for it), and seem to have treated their suspect with at least a small measure of dignity. None of those conclusions fits the encounter with Ms. Davis. The amount of police explanation was comparable in the two cases, but the difference between the two crimes makes the explanation in the

107. Id. at 78-79 (second and third ellipses in original). 
second case seem questionable. Ms. Davis was treated both rudely and roughly. It is no surprise that while Mr. Reyes concludes his description, in a passage omitted above, by saying that he "was embarrassed" and did not tell his mother about the encounter "because I didn't want to upset her," 108 Ms. Davis concludes her account by emphasizing her anger. ${ }^{109}$ The anger is understandable.

Yet the law takes no account of it. Speed, proportionality, providing a good explanation for the stop, and treating the suspect with some respectthese things are not on Terry's list of requirements. Nor could they be: Some police-citizen encounters are of necessity drawn out, coercive, rough, and disrespectful. Yet that proposition shows only that hard-and-fast rules are inappropriate in this context. It does not show that legal regulation of the manner of Terry stops is impossible.

And it is the manner of the stop-the degree of disrespect and force the officers display - that largely determines how the suspect will react: with mild embarrassment, or with rage. That much follows from Tom Tyler's well-known work on citizens' attitudes toward the law and toward those who enforce it. Tyler's work finds that individuals' responses to law enforcers depend not on the outcomes of their encounters but on whether the individuals thought they were treated fairly-with "fairness" captured by a trio of factors Tyler labels neutrality, benevolence, and status recognition. ${ }^{110}$ According to a recent study by Tyler and Yuen Huo, this process-based response explains why blacks and Latinos are more dissatisfied than whites with their treatment by the police; it also explains why the first two groups are likely to be less compliant in encounters with police than the third. ${ }^{111}$ Importantly, both dissatisfaction and noncompliance persist despite nearly identical perceptions about outcomes in police encounters among the three groups. ${ }^{112}$

For present purposes, there are three conclusions to be drawn from Tyler's work. First, the manner, and the manners, of street stops probably have a larger effect on suspects' views of the police than does their selection as suspects. Second, discrimination in street policing may have more to do with the way police treat different categories of suspects than with how many people in each category are stopped. It follows from those two propositions that even if the law successfully regulated police selection

108. Id. at $77-78$.

109. Id. at 79 .

110. This basic finding forms the core of a number of works. See, e.g., YUEN J. HUO \& TOM R. TYLER, HOW DIFFERENT ETHNIC GROUPS REACT TO LEGAL AUTHORITY (2000); TOM R. Tyler, Why People Obey the Law (1990); Tom R. Tyler, Trust and Law Abidingness: A Proactive Model of Social Regulation, 81 B.U. L. REv. 361 (2001) [hereinafter Tyler, Trust and Law Abidingness].

111. See HUO \& TYLER, supra note 110 , at $21-26$.

112. See id. at $27-38$. 
of targets, the level of racial distrust in policing would remain high. The third conclusion makes this a win-win issue, a chance to improve the welfare of both suspects and police: If street stops were carried out more politely, if suspects were treated with more dignity, the level of suspect compliance with the police would rise. That would presumably mean more consensual searches-a boon for the police. It might also mean a rise in police safety: Tyler notes a sizeable body of social science research that suggests that the risk of violence rises with the level of police aggression. ${ }^{113}$

If Tyler's claims are even partly true, the police could simultaneously increase the number of Terry stops, decrease the injury those stops cause, and substantially reduce complaints of police discrimination - all without changing the way they select search targets. If that is true, the law clearly has its grip on the wrong lever. Worrying about how street stops happen makes more sense than worrying about how many of them happen.

Integrating that insight into Fourth Amendment law is not easy. The line between decent and indecent police treatment of suspects is, to say the least, unclear. The proportionality of the stop depends on the suspected crime. The roughness and degree of respect that officers display can be evaluated only in terms of the nature of the threat the suspect poses and the circumstances in which the stop is made. These things would seem to vary almost infinitely. Perhaps, then, there is little the law can do beyond telling police officers to behave reasonably - and such vague standards, the conventional wisdom holds, amount to no standards at all.

But the problem is not so intractable, because the variations are not as great as they would seem. The police do not investigate an infinite number of crimes, or even a particularly long list. The large majority of Terry stops are based on suspicion of one of a half-dozen offenses. ${ }^{114}$ And while suspects' behavior varies more widely, there too, the likelihood is that officers--and courts-see a manageable number of fact patterns. There may be many cases that look pretty much like Mr. Reyes's stop, and many others that look like Ms. Davis's. The same range of fact patterns seems to permit a reasonable degree of predictability when it comes to applying the probable cause and reasonable suspicion standards, which are themselves vague. (Not to mention the "seizure" standard, which is as vague, and vague in the same ways, as the kind of fair treatment standard I advocate here. $)^{115}$ Just as many jurisdictions have a functional local common law of

113. See Tyler, Trust and Law Abidingness, supra note 110, at 368-72,383-85.

114. See STOP \& FRISK REPORT, supra note 106, at 110 tbl.I.A.5 (showing that sixty-nine percent of stops in New York City are for violent crimes, weapons offenses, or property crime). The report does not offer a morc detailed breakdown, but one can reasonably assume that the dominant violent crimes are assault and robbery, the main weapons offense is some form of illegal possession of a gun, and the property crimes are mostly some species of theft.

115. See supra note 102. The working definition of "seizure" depends on an open-ended assessment of the coerciveness of the officer's behavior toward the suspect. Coercion is judged in 
probable cause, judges and magistrates might fashion, over time, bodies of local common law of reasonable treatment.

There is a broader point to be made here. The central problem with regulating the manner of street stops is definition: No one knows how to craft a legal formula that will tell officers how to behave in advance. That problem, however, need not be solved; vagueness in legal definitions is a more tolerable vice than law professors tend to think. The problem that needs addressing is not definition but application-the question is not whether we can come up with the right legal terminology, but whether police officers can know roughly where the boundaries are in practice. ${ }^{116}$ Maybe they can. "I know it when I see it" 117 has a bad reputation in legal circles, but the reputation is undeserved. Sometimes, consider-all-thecircumstances standards work tolerably well in spite of their linguistic muddiness-for all the muddiness, bottom lines may be reasonably predictable. After all, it seems clear enough that Mr. Reyes was treated reasonably, and Ms. Davis was not.

context, based on the surrounding circumstances. (Thus, in Florida v. Bostick, 501 U.S. 429 (1991), the bulk of the Court's opinion concemed the ways in which the setting-a Greyhound bus-did or did not alter the nature of the relevant police conduct.) A ban on rude police behavior, though it sounds impossibly vague, thus amounts to the same sort of legal regulation as the definition of "seizure." As there are no complaints that the "seizure" cases are impossible for officers to understand or for courts to apply, perhaps vagueness in this context is not such a bad thing after all.

116. That raises another problem. In order for police to know where the boundaries are, judges must be able to find the relevant facts, and factfinding in suppression hearings is hard. This is so for two reasons: Suspects have an incentive not to take the stand-if they do so, anything they say can be used to impeach them at a later trial-and police officers have an incentive to shade the truth. The result is a swearing contest where only one side swears, and may well swear falsely. These effects may be especially severe when it comes to the regulation of the manner of street stops, since any such regulation requires fairly rich factual accounts.

That problem may be devastating, but I doubt it. First, the evidence suggests that while police sometimes lie in suppression hearings, they do not lie very effectively-judges can generally tell the difference between a self-serving story and the truth. This can be deduced from the combination of two facts: Police lie frequently, yet defendants win a significant fraction of suppression motions. On the first fact, see, for example, Myron W. Orfield, Jr., Deterrence, Perjury, and the Heater Factor: An Exclusionary Rule in the Chicago Criminal Courts, $63 \mathrm{U}$. COLO. L. REv. 75 (1992). Orfield's study suggests that police perjury succeeds mainly in cases where the crime charged is sufficiently serious that, in the judge's eyes, suppression seems inappropriatc. Id. at 83 . That phenomenon turns more on judicial nullification than on police perjury. On the second fact, see Peter F. Nardulli, The Societal Cost of the Exclusionary Rule: An Empirical Assessment, 1983 AM. B. FOUND. RES. J. 585. Nardulli's study is generally taken to prove that successful exclusionary rule claims are exceedingly rare, but they are actually about as common as acquittals at trial: Both occur in about one percent of criminal cases. Compare id. at 598 tbl.8, with SOURCEBOOK OF CRIMINAL JUSTICE STATISTICS-1999, at 460 tbl.5.62 (Ann L. Pastore \& Kathleen Maguire eds., 2000) [hereinafter 1999 SOURCEBOOK]. A better measure of defendants' success rate in suppression motions is the percentage of such motions that are granted; there, Nardulli finds a success rate of $16.9 \%$ for suppression of physical evidence. Narduli, supra, at 596. This figure is likewise comparable to defendants' success rate at criminal trials. See 1999 SOURCEBOOK, supra, at 460 tbl.5.62 (showing a five-to-one ratio of trial convictions to acquittals).

117. The reference is to Jacobellis v. Ohio, 378 U.S. 184, 197 (1964) (Stewart, J., concurring). 
That kind of predictability is particularly likely where the regulated actors regularly confront the relevant legal standard. Police officers are a classic example. They are frequent witnesses in suppression hearings, where they see their conduct reviewed by local magistrates. Consequently, they have much better information about the law-as-applied than most other regulated actors. To put the point another way: Police officers are more like insurance adjusters than like doctors. Both adjusters and doctors are subject to legal regulation by a hopelessly vague negligence standard (no less vague than a reasonable treatment standard for street stops), and both must make judgments about pricing and behavior based on how that standard is likely to be applied in various fact settings. But the insurance adjusters have a large advantage: They see the standard applied frequently-insurance companies are in the business of litigating and settling tort claims. Doctors see it only when they or their friends are sued. Police officers fall somewhere in between on this spectrum, but closer to the insurance adjusters, given how frequent suppression hearings are. It follows that vagueness is less of a problem in this setting than is commonly assumed.

Even if that view is too sanguine, it is hard to justify the nonregulation of the manner in which searches are carried out. The best defense of the law as it stands now goes something like this: We regulate what doesn't matter much (whether the search happens) because we can regulate it reasonably well, and we ignore what does matter (how the search happens) because we can't do much about it. That is "under the light" disease, ${ }^{118}$ with a vengeance. At the very least, we ought to see whether it is possible to regulate what does matter.

\section{Profiling as a Second-Best Problem}

What does any of this have to do with profiling? In a direct sense, nothing. Profiling describes a means by which suspects are identified and selected by the police. (Indeed, in a sense it describes the only means by which suspects are identified and selected-by a set of characteristics that fit the person or persons for whom police are looking. The process is controversial only when the characteristics are racial or ethnic and the class of people whom police are seeking is either large or poorly defined.) Neither of these proposed reforms-allowing group searches and seizures, and regulating the manner of street stops-bears on the ways in which police identify suspects.

118. The reference is to the famous line about the man looking for his car keys on a city sidewalk under a streetlight at night. Another man approaches and asks what the first is doing; he responds, "Looking for my car keys." The second man asks, "Did you lose them here?" When the first says no, the second asks why he is looking there if he didn't lose his keys there. The answer: "Because it's easier to look under the light." 
But in another sense, these reforms have a great deal to do with the enterprise of profiling. First, this is an area in which direct regulation is probably impossible. Second, substantial mitigation of the harms that flow from this practice is possible.

Take these points in turn. If using race is a problem when selecting targets of police attention, the solution would seem to be simple: Don't use race. That is the conclusion reached by Randall Kennedy, author of the leading discussion of profiling in the literature. ${ }^{119}$ As Kennedy shows, that conclusion does not depend on the view that all profiling is racist. Even if police officers rationally use race as a proxy for some kinds of criminal behavior, doing so imposes a "racial tax" -in effect, the police make it more expensive to be black than to be white. ${ }^{120}$ Just as explicit racial taxes violate the Constitution and offend basic equality norms, so do the implicit kind.

While Kennedy's argument is powerful, the racial tax he describes is not so easily abolished. Courts can, of course, say that race cannot be used to justify searches and seizures (though even there, one must make an exception for descriptions of individual suspects). But racial profiling does not require using race as a legal justification. The state troopers who stopped black motorists along I-95 (the subject of the most famous profiling studies $^{121}$ ) did not need to defend those stops in court by arguing that blacks were more likely than whites to have drugs in their cars, even though that assumption surely motivated many of the stops. Indeed, if any of the stops were challenged in court, the troopers would not need to say anything at all about race or drugs. Under existing Fourth Amendment law, it is enough that the troopers had probable cause to believe the motorists were violating traffic rules ${ }^{122}$ - which was surely true, since all drivers violate highway speed limits when traffic permits. Doing away with race as a justification for the stops accomplishes nothing, for the troopers have more than enough justification without it.

That conclusion would hold even if pretextual stops were illegal. The list of nonracial observable characteristics associated with crime is long. If speeding will not suffice to justify a stop, perhaps slowing down upon seeing a police car will. ${ }^{123}$ Or driving a kind of car associated with drug

119. Randall KenNedy, RaCE, CRIME, AND tHE LAw 138-63 (1997). Although Kennedy does not call the phenomenon "profiling," the kind of police discrimination he discusses in these pages is precisely the kind that travels under that label today.

120. Id. at $158-60$.

121. For a detailed discussion of the studies, see Harris, supra note 92.

122. Or reasonable suspicion of any other offense. See, e.g., Delaware v. Prouse, 440 U.S. 648,661 (1979). The probable cause requirement is easily satisfied with respect to traffic violations, since those violations are almost always readily observable-once the police see a car speeding or driving with a broken headlight, they have probable cause to believe the driver has violated the traffic code.

123. See, e.g., United States v. Arvizu, 122 S. Ct. 744, 752 (2002). 
trafficking-which (believe it or not) might mean a minivan full of children. ${ }^{124}$ Factors like these take in a large number of motorists of different races but permit the police to target only some, or only one, of those races-remember that courts never see the motorists the troopers don't stop. Because courts are poorly positioned to tell which factors are really associated with drug dealing-the relevant data sets either do not exist or are not public-courts are likely to take the word of the police. ${ }^{125}$ This practice leaves officers free to use race as a proxy for one or another kind of crime whenever they see fit. ${ }^{126}$

And they often will. That much follows from the proposition that profiling may be rational from the officers' point of view. ${ }^{127}$ Crime corresponds to local demographic patterns; in any given city, the population of burglars or arsonists is bound to belong disproportionately to one or another ethnic group. Some patterns transcend local conditions: Everywhere, young men commit a hugely disproportionate number of crimes. Police know these things. They can hardly be expected to forget what they know.

In a world where criminal organizations buy and sell drugs-and where other sorts of criminal organizations use hijacked airplanes to blow up buildings-the problem is worse still. Criminal enterprises are not equal opportunity employers. As Janet Landa's work on Asian commercial markets shows, where legal protections do not operate, ethnic bonds can serve as a substitute, a means by which market actors reduce the risk of cheating by those with whom they deal. ${ }^{128}$ The same idea applies to illegal enterprises. It follows that drug distribution networks and terrorist organizations, like Mafia families, are bound to have a racial or ethnic cast. The police, whether FBI agents looking for members of al Qaeda or local cops trying to break up a heroin ring, are bound to know what the relevant racial or ethnic cast is. If the law asks them to feign ignorance, the likely

124. See id. at 749 (describing a minivan as "a type of automobile that ... smugglers used"). The minivan in Arvizu contained two adults and three children. Id.

125. For a classic example, see Ornelas v. United States, 517 U.S. 690 (1996). In that case, the officer justified searching behind a loose panel of the suspect's car based on the fact that the panel was loose and contained a rusty screw, which suggested to the officer that the panel might have been removed and drugs placed behind it. There are two relevant empirical questions in such a case: How many similarly loose panels hide illegal drugs, and how many don't? Naturally, the Court had no idea what the answers to those questions were-nor did the district judge or the court of appeals panel before it. So the Court emphasized the officer's testimony that loose panels often hide drugs and left it at that. The result was a defense victory, but only nominally: As David Sklansky notes, Ornelas reinforced the tendency to credit police officer testimony in such cases. See Sklansky, supra note 8, at 300-01.

126. This is even more true when we move from vehicular to pedestrian traffic. The more visual characteristics officers can observe, the longer the list of factois they can plausibly claim are associated with crime.

127. See Gross \& Livingston, supra note 81 (manuscript at 8)

128. See Janet T. Landa, A Theory of the Ethnically Homogeneous Middleman Group: An Institutional Alternative to Contract Law, 10 J. LEGAL STUD. 349 (1981). 
effect is not to reduce the role ethnicity plays in policing, but rather to reduce the respect the law enjoys among the police.

In short, racial and ethnic profiling is a fact of life that the legal system probably cannot change. This makes profiling a classic "second best" problem: The optimal result-no race-conscious policing, the total elimination of Kennedy's racial tax-is impossible, so the relevant question is, what is the best among the set of suboptimal results that the legal system can produce?

There is one more hurdle to be cleared before answering that question. The question assumes that an optimal regime would indeed ban raceconscious policing, but that assumption may be wrong. (In my view, it is.) The inefficiency of treating all airplane travelers the same-should airport security officials really regard travelers with Danish visas and travelers with Yemeni visas as equally risky?-is both great and obvious. Reasonable people can differ about the balance, but one could plausibly conclude that the efficiency gains from profiling outweigh the harm from the ethnic tax that post-September 11 policing is imposing on young men of Middle Eastern origin.

Yet that conclusion does not much affect the argument. Even those who, like me, regard racial or ethnic profiling as occasionally tolerable must agree that it is usually a very bad thing. It all depends on the balance, on the benefits to law enforcement from using race or ethnicity as a proxy and the harm to the group that must pay Kennedy's tax. ${ }^{129}$ The police internalize only the benefits. ${ }^{130}$ Consequently, they are likely to take race and ethnicity into account even when doing so is socially harmful. One is left with a world in which a lot of profiling is both socially destructive and impossible to prevent. In such a world, the legal system must choose among second-bests.

Choosing wisely requires that attention be paid to the nature of the injury profiling causes. Kennedy's racial tax is not a constant; on the contrary, the harm from police-citizen interactions varies enormously. Even if the system cannot eliminate race-based selection of suspects (as it plainly cannot), it may still be able to reduce the injury those suspects feel once they are selected.

The two best ways to do that are outlined above. First, give the police an incentive to substitute, at the margin, group seizures for individual

129. Even when the benefits of profiling exceed its costs, it may sometimes be a social bad. Profiling imposes a regressive racial tax; it tends to be paid disproportionately by those at the bottom of the social and economic ladders. The more one cares about distributive justice, the more one might wish to see profiling's benefits strongly outweigh its (nondistributive) harms before concluding that it is socially beneficial.

130. This is an oversimplification. It would be more accurate to say that police internalize profiling's costs only through the political system, and therefore only partially. That is the upshot of the takings analogy discussed supra notes 87-89 and accompanying text. 
seizures. The former reduce or eliminate the targeting harm that characterizes the latter, so any substitution is bound to reduce aggregate injury. Plus, group searches and seizures are more transparent than the individual kind, meaning that politics can better regulate them. Second, place legal limits on the coercion-and rudeness-police inflict on suspects during the course of street stops. If the limits worked, they would reduce harm directly. Police selection of suspects would not be greatly affected, meaning that race and ethnicity would probably be overused, as they almost certainly are today. But the costs of overuse would be smaller. Given the difficulty of the problem, that is a goal well worth pursuing.

\section{B. Secret Searches}

The two reforms proposed in the preceding Section-permit group searches and seizures, limit the harshness of individual searches and seizures-bear on tactics that local police use (or, in the case of group seizures, would probably like to use) regularly. The next proposal is different. Most searches police undertake are visible to the targets of those searches, either at the time of the search or soon after. Suspects generally know when their homes or cars have been searched, and they necessarily know when they have been frisked or searched incident to arrest. That visibility is a large protection, for it means that police cannot behave illegally, all the while knowing that the illegality will go unseen.

Secret searches are a good deal more dangerous-consider the awful power of the phrase "secret police" - and, thankfully, a good deal more rare. They may not be rare for long. The mushrooming of surveillance cameras in Great Britain has shown both that such devices are affordable and that the citizenry of a Western democracy will tolerate them. ${ }^{131}$ And the ease of some kinds of Internet searches may make them increasingly attractive to local police departments with stretched manpower seeking more efficient ways to catch criminals. Surveillance cameras can be hidden, and users of online services may not realize they are being searched.

If there is a trend here, federal antiterrorism legislation passed last October reinforced it. That legislation permits roving wiretaps on order of the Foreign Intelligence Surveillance Court, ${ }^{132}$ authorizes the use of sneakand-peek warrants if a judge finds that giving notice of the search might harm the government's investigative interest, ${ }^{133}$ and-most important of all - grants essentially free access to "dialing, routing, addressing, and

131. See Jeffrey Rosen, A Watchful State, N.Y. TimeS, Oct. 7, 2001, § 6 (Magazine), at 38.

132. USA PATRIOT Act, supra note $2, \S 206,115$ Stat. at 282.

133. Id. $\$ 213,115$ Stat. at 285 . 
signaling" information in Internet communications. ${ }^{134}$ What that last phrase means is not entirely clear, but it apparently includes the e-mail addresses of one's correspondents and the websites one has visited. ${ }^{135}$

Both the sneak-and-peek warrants and the Internet searches apply to federal criminal investigations generally, not merely to antiterrorism work. Even so, those provisions of the Patriot Act might not be terribly important in themselves, since the huge majority of law enforcement officers work for local governments and enforce state criminal law. ${ }^{136}$ Still, if these federal powers are deemed constitutional, one can expect to see state legislatures granting the same powers to the police who work in their jurisdictions. If the provisions of the Patriot Act are constitutional, they might soon define the baseline for all American policing.

The searches those provisions authorize pose serious regulatory problems. If nothing else, their invisibility is a powerful threat. Whether or not Big Brother is actually watching, if people think he might be, they will alter their behavior accordingly. This may be the real source of the power of secret police in authoritarian countries: You never know when you are being monitored, so you must always watch your step.

Surely that is a risk worth worrying about. The question is, how can the law minimize it? There are three plausible regulatory strategies for dealing with secret searches; current law makes use of the first two but not the third. Yet the third is probably the best.

The first is prohibition. This need not mean a ban on all secret investigative tactics-police sometimes need to act secretively. Tactics like wiretaps and undercover agents are not only useful; they are sometimes essential to the enterprise of cracking open organized crime networks. ${ }^{137}$ The prohibition strategy can accommodate that need by banning only some classes of secret searches (e.g., those where police lack probable cause), by banning only certain tactics (e.g., programs that scan e-mail traffic), or by a combination of the two. This approach has some obvious strengths. It follows the pattern set by the rest of Fourth Amendment law, which basically allows some kinds of searches and forbids others based on rough balances of the relevant interests. But it is unlikely to work well with secret searches, because the police will always be tempted to go beyond the law's

134. Id. $\$ 216,115$ Stat. at 288 . Officers must get "trap and trace" orders in order to obtain this information, but thosc orders are a formality. The only precondition is that the information sought be relevant to a criminal investigation. Id.

135. That is the ACLU's analysis. See Am. Civil Liberties Union, How the USA-PATRIOT Act Limits Judicial Oversight of Telephone and Internet Surveillance, at http://www.aclu.org/ congress/L102301 g.html (last visited Jan. 17, 2002).

136. For the numbers, see supra note 3.

137. See, e.g., Gary T. MARx, Undercover: Police Surveillance in America 37-40 (1988) (discussing the use of undercover agents to attack white-collar crime networks); James B. Jacobs \& Lauryn P. Gouldin, Cosa Nostra: The Final Chapter?, 25 CRIME \& JUST. 129 (1999) (emphasizing the role wiretaps played in bringing down major Mafia families). 
bounds-after all, most of the time, their illegality will go undiscovered. The temptation is likely to be particularly strong where the prohibitions are fuzzy. Clear lines-no Internet searches-may work reasonably well. Officers may know that most violations will never be discovered, but they will also know that any violations that are discovered will be punished because the boundary line is so clear; there is no room for finessing the problem. Vague standards like probable cause or reasonable suspicion do not share that virtue. The secrecy of the search means most transgressions will escape scrutiny; the vagueness of the legal boundary means that even when the search is discovered, the officer has a shot at victory. In that kind of system, the ex ante cost of crossing the legal boundary is very small. Where violations are cheap, we should expect lots of violations.

In short, prohibitions of secret searches can only work where the prohibitions are clear and categorical. This is a point often made about legal regulation of policing; one of the most common lines in Supreme Court cases is that the police need clear rules. Usually, that line is wrong: Police are actually better able to apply vague legal standards than almost any other regulated actors. In this context, though, the advocates of clear rules have it right. Since clear, categorical lines are hard to come by in this context, it follows that the prohibition strategy has it wrong.

The second regulatory strategy is a good deal better, and to Congress's credit, we see some instances of it in the Patriot Act. ${ }^{138}$ The law could require disclosure in advance of the search, by forcing police to get a magistrate's permission in order to engage in the relevant secret search tactic. This has been the law's stance toward wiretaps for the past generation, ${ }^{139}$ and the consensus appears to be that the regulation of wiretaps has been reasonably successful. ${ }^{140}$ Yet a warrant requirement has an important downside. Law generally regulates by imposing sanctions after the fact, when a violation has already occurred and harm has resulted. That is the near-uniform pattern because it is vastly more efficient than litigation before the fact. If one waits until afterward, most cases will be disposed of-the regulated actor will comply with the regulation or injure no one, and there will be nothing to litigate. Before the fact, one must

138. See USA PATRIOT Act, supra note 2, $\$ 206,115$ Stat. at 282 (authorizing warrants for non-place-specific wiretaps to be issued by the Foreign Intelligence Surveillance Court); id. $\$ 213$, 115 Stat. at 285 (authorizing the issuance of sneak-and-peek warrants); id. $\S 216,115$ Stat. at 288 (authorizing trap and trace orders for Internet surveillance).

139. Berger v. New York, 388 U.S. 41 (1967) (requiring this as a matter of Fourth Amendment law). Congress effectively displaced Berger with a detailed statutory scheme in Title III of the Omnibus Crime Control and Safe Streets Act of 1968. Pub. L. No. 90-351, tit. III, 82 Stat. 197, $211-25$ (codified at 18 U.S.C. $\$ \$ 2510-2522$ (1994)).

140. The best evidence for this proposition is negative. There is an enormous literature on the law of search and scizure, and the great majority of it is highly critical. Wiretaps receive amazingly little attention in that large literature. The likely reason is the sense that the regulatory regime prevents the worst police abuses. 
litigate everything. ${ }^{141}$ So it is with warrants: If police must get them in order to search houses, every house search (save for the occasional exigency) will be preceded by a warrant application. If, on the other hand, the probable cause requirement for house searches were enforced only after the fact in suppression hearings, most house searches would produce no litigation, either because the police found no evidence or because they clearly had probable cause. Like any pre-event litigation process, the warrant requirement tends to generate lots of litigation.

Reacting to this problem, warrant requirements tend to oscillate between two bad poles. Water down the warrant process to make it affordable, and the process becomes pointless; magistrates turn into rubber stamps and the virtue of asking their permission disappears. Make the process a serious screen, and it becomes expensive enough that the police hardly ever use it; the warrant functions as a de facto prohibition. The former phenomenon seems to characterize most search warrants. ${ }^{142}$ The latter may capture the warrant process for approving wiretaps: Nationwide, the number of taps is only a little over one thousand per year, ${ }^{143}$ a tiny number in a system that makes fifteen million arrests per year. ${ }^{i 44}$ Perhaps the regulation of wiretaps is not so successful after all-existing law may not so much regulate wiretaps as smother them.

The third regulatory strategy, the one neither the Patriot Act nor Fourth Amendment law embraces, has neither of these problems. Instead of limiting what search tactics the government can use or requiring permission when it uses them, we could limit what the government does with the information once it has it. The law could allow a given search tactic whenever the police want to engage in it, but forbid public disclosure of

141. I have made this argument at greater length elsewhere. Stuntz, supra note 30 , at 885-88.

142. The general assumption is that the search warrant process is a rubber-stamp process. The leading study of that process tends to validate that assumption:

Based on our observations and intervicws, the rate of outright rejection [of warrant applications] is extremely low. Most of our police interviewees could not remember having a search warrant application turned down.... Of the 84 warrant proceedings observed, 7 resulted in denial of the application ( 8 percent).

VAN DUIZEND ET AL., supra note 29 , at 32 . The eight percent figure probably overstates the rate at which applications are denied, since magistrates are more likely to review applications with care when they are being observed by third parties than when only the magistrate, the police officer, and perhaps a court reporter are present.

Perhaps surprisingly given this pessimistic conclusion, the success rate of searches pursuant to warrants is very high. See id. at 51 tbl.2-20 (showing that police in the seven jurisdictions studied found most of the items listed in the warrant in between sixty-four and eighty-two percent of searches). The delay and paperwork involved for police officers leads the officers to use the warrant process carefully, not for fear that magistrates will reject applications, but in order to avoid wasting time filling out forms and waiting around courthouses.

143. See 1999 SOURCEBOOK, supra note 116, at 384 tbl.5.3 (showing a total of 1329 wiretap orders for 1998 , with 566 issued by federal courts and 763 by state courts).

144. See Bureau of Justice Statistics, U.S. Dep'T OF Justice, Sourcebook of Criminal Justice Statistics-1998, at 328 tbl.4.l (Kathleen Maguire \& Ann L. Pastore eds., 1998) (showing 15.3 million arrests for 1997). 
anything uncovered save in a criminal trial. (That might be a good limit for all police searches. $)^{145}$ To ensure that the tactic is not used too often or too arbitrarily, we might also limit the range of crimes the government can prove by evidence discovered through that tactic. It is one thing if the police are searching e-mail traffic for evidence in murder cases, but quite another if they are searching for evidence of any crime. Murder investigations put few e-mail users at risk of privacy invasion. Criminal codes are broad enough that if all crimes "count," as they do for other searches, everyone is at risk. This is not to say that only murders (or, as with terrorist threats, potential murders) should be enough to trigger authority to search. But where the search tactic is both secret and potentially invasive, it should probably be limited to the investigation of violent felonies. The best way to ensure that result is to bar the use of such evidence to prove other, lesser crimes.

This approach gets at the most serious problems with Big Brotherism, the twin threats that authoritarian societies depend on: that ordinary citizens will be punished for ordinary behavior, and that dissidents will be punished for making trouble for those in power. The first threat makes it impossible for people to know how to stay out of jail and thus forces the mass of the population to look for ways to curry favor with the authorities. The second threat reinforces the first; by making criticism impossible, it kills dissident networks before they are born. Notice that both are substantive: They have to do not with what information the government can find out about its citizens, but with what behavior the government can punish. The best way to guard against them is with substantive limits-limits on what the government can call a "crime," and hence on whom the government can throw in jail.

Outside of the First Amendment and a few pockets of due process and equal protection cases, we have no history of such limits. ${ }^{146}$ As a

145. The need for some such limit is a good deal clearer after the spate of exceedingly public investigations by independent counsels in the $1990 \mathrm{~s}$. For a good discussion of the kinds of privacy invasions those investigations-and especially the disclosure that followed them-entailed, see JefFrey Rosen, The Unwanted Gaze: The Destruction of Privacy in America (2000). For a pair of early arguments in the literature for privacy protection that focused on disclosure, see Seth F. Kreimer, Sunlight, Secrets, and Scarlet Letters: The Tension Between Privacy and Disclosure in Constitutional Law, 140 U. PA. L. REV. 1 (1991); and Harold J. Krent, Of Diaries and Data Banks: Use Restrictions Under the Fourth Amendment, 74 TEX. L. REV. 49 (1995).

The historical norm has been to permit the police to do anything with information that they obtain legally, but of late, the Supreme Court seems to have taken an interest in limiting extraneous publicity. See Wilson v. Layne, 526 U.S. 603 (1999) (finding a house search unconstitutional where police officers were accompanied by newspaper reporters and photographers). But there is still no constitutional limit on disclosure of information once obtained-notice that Wilson dealt with publicity that was coincident with the search.

146. There was a brief time, in the late 1950 s and early 1960 s, when the Supreme Court seemed about to create a body of substantive due process doctrine aimed specially at criminal law. See Lambert v. California, 355 U.S. 225 (1957) (invalidating a felon registration statute on lackof-notice grounds); Robinson v. California, 370 U.S. 660 (1962) (overturning a conviction for 
consequence, American criminal codes are like Sherwin-Williams paint: They cover the Earth. The sheer breadth of criminal liability rules makes it fairly easy, when the police need no suspicion in advance of the search, to attach whatever they find to some crime. So it is especially important that evidence obtained from searches that are both secret and suspicionless be used to prove only serious crimes, the kinds of crimes that the government would not prosecute pretextually.

The other limit suggested above-no public disclosure outside of a criminal trial-serves to ensure that problematic search tactics will not be abused. If the police can disclose what they find, innocent but embarrassing discoveries can be the basis of a kind of blackmail. As there is no obvious law enforcement need for disclosure, this limit seems like a rare example of a nearly costless protection. Also one that nicely mirrors the solution our society has embraced for a whole host of necessary-but-potentiallyproblematic privacy intrusions: The IRS can find out a good deal of private information about my finances, but agents cannot leak that information to the local press or turn it over to just any government actor who asks for it. The consequence is that my privacy is reasonably well-protected, even while the government gets the information it needs to assess my tax liability. A good many employers have drug-testing policies that explicitly restrict the use of information they get from the tests-including restrictions on turning the information over to the police. The principle is the same.

In short, outside the Fourth Amendment's realm, privacy is generally protected not by banning the gathering of information or by requiring some elaborate advance permission, but by placing serious limits on what happens to the information once it is gathered. If that is how we protect our privacy in areas where politics govern (e.g., the IRS) and where markets govern (e.g., employers' drug-testing policies), perhaps it is a useful model to follow where constitutional law governs. Fourth Amendment law has not embraced such limits on searches like the ones the Patriot Act authorizes, but it should. That would allow us to give both the police and private citizens more of what they value-easier evidence-gathering and reduced risk of embarrassment or harassment.

drug addiction on the ground that addiction was involuntary); Griswold v. Connecticut, 381 U.S. 479 (1965) (overturning a criminal ban on contraceptives on the ground that the ban infringed marital privacy). But the moment passed, and the Court turned instead to the constitutionalization of criminal procedure, leaving substantive criminal law largely unregulated. For an account of this process and some speculation about why the Court chose as it did, see William J. Stuntz, The Uneasy Relationship Between Criminal Procedure and Criminal Justice, 107 YALE L.J. 1, 66-74 (1997). 


\section{Interrogation ${ }^{147}$}

Unlike Fourth Amendment law, where change seems the only constant, the law of police interrogation has been fairly stable for the past two decades. When police take a suspect into custody and prepare to question him, they must give him the famous Miranda warnings. ${ }^{148}$ If, having heard the warnings, the suspect talks, waiver is presumed. ${ }^{149}$ If the suspect refuses to talk, if he utters some form of Miranda's magic words-_." I don't want to talk; I want to see a lawyer"-questioning is barred. ${ }^{150}$ If the suspect agrees to talk but after a period of questioning changes his mind and utters the magic words then, the interrogation is over. ${ }^{151}$ All these propositions were settled by $1981 ;^{152}$ the cases since then have made only marginal refinements to Miranda's structure.

One reason for this stability is that, contrary to popular impressions, police officers do not much mind Miranda. ${ }^{153}$ They lose little that they care about and get most of what they want. That is why the recent effort to get the Supreme Court to overturn Miranda, or at least to uphold legislation that would do so, was the product of ideologically driven lawyers and not disgruntled cops. ${ }^{154}$ Yet the cops may not be satisfied with the status quo for long. September 11 may have changed Miranda's politics as it changed a good deal else.

147. Most of the argument in this Section is developed at greater length in William J. Stuntz, Miranda's Mistake, 99 MiCH. L. REV. 975 (2001).

148. Miranda v. Arizona, 384 U.S. 436 (1966).

149. This is not the way the cases put it, but it accurately describes the reality. North Carolina v. Butler, 441 U.S. 369 (1979), holds that waiver can be implied from the suspect's conduct. The conduct that generally "implies" waiver is simply talking to the police after the warnings have been read.

150. See Edwards v. Arizona, 45i U.S. 477 (1981) (holding that if the suspect invokes the right to counsel, questioning is barred until the suspect reinitiates contact); Michigan v. Mosley, 423 U.S. 96 (1975) (holding that if the suspect invokes the right to remain silent only, questioning is barred for a period of time). In practice, suspects almost never invoke only the right to remain silent; they invoke either both rights or the right to counsel. The strongest evidence for this proposition is the near-total absence of litigation about the boundaries of Mosley's invocation rule.

151. Edwards, 451 U.S. at 482.

152. See cases cited supra notes 148-151.

153. A 1988 American Bar Association survey found general agreement among police officers with the proposition that neither the Fourth Amendment's exclusionary rule nor Miranda posed any serious problem for the police. AM. BAR ASS'N SPECIAL COMM. ON CRIMINAL JUSTICE IN A FREE SOC'Y, CRIMINAL JUSTICE IN CRISIS 12-20, 28-30 (1988).

154. The key actor was Paul Cassell, who wrote the amicus brief that persuaded the Fourth Circuit to uphold the 1968 statute that purported to overturn Miranda in federal courts. See United States v. Dickerson, 166 F.3d 667, 681-82 (4th Cir, 1999), rev'd, 530 U.S. 428 (2000). Cassell's brief arose out of a body of scholarship attacking Miranda and defending Congress's power to overrule it. See, e.g., Paul G. Cassell, Miranda's Social Costs: An Empirical Reassessment, 90 Nw. U. L. REV. 387 (1996); Paul G. Cassell, The Statute That Time Forgot: 18 U.S.C. \& 3501 and the Overhauling of Miranda, 85 IOwA L. REV. 175 (1999); Paul G. Cassell \& Richard Fowles, Handcuffing the Cops? A Thirty-Year Perspective on Miranda's Harmful Effects on Law Enforcement, 50 STAN. L. REV. 1055 (1998). 
To see why, we must return to Miranda's basic structure. The key is the invocation rule, which says that questioning has to stop once the suspect invokes his Miranda rights (in particular, his Miranda right to counsel). ${ }^{155}$ Invocation is the means by which Miranda regulates police questioning. The theory is roughly as follows. If the police behave badly-if they browbeat, threaten, or otherwise abuse the suspect-the suspect will naturally be frightened, and if he is frightened he will call for a lawyer's help. Once he calls for help, questioning is finished and cannot begin again except at the suspect's instigation. That is a serious penalty from the point of view of the police; when the suspect invokes, the police lose whatever chance they had to get an admissible confession. The police respond to that threatened sanction by avoiding anything that might prompt the suspect to invoke. Browbeating, threats, abuse of any kind - anything that has the effect of turning up the heat on an already frightened suspect-all become counterproductive. The upshot is kinder, gentler interrogation, questioning that turns the heat down rather than up, so as to keep the suspect talking to the police and not to his attorney.

The theory is elegant. If Miranda works as it should, it allows suspects to define how much police pressure is too much, and so spares judges the need to engage in the messy business of determining which statements are voluntary and which are compelled. It also gives the police an incentive to take careful account of suspects' interests, and so guards against abusive questioning.

But the theory can only work under certain conditions, and the conditions are almost never satisfied. The best study of Miranda in practice found that only one percent of suspects invoked their rights once questioning had begun. ${ }^{156}$ This is unsurprising. Invocation is both an act of power by which the suspect takes control of his conversation with the police, and an act of rational self-interest by which he avoids talking his way into a prison cell. Frightened suspects in police interrogation rooms are not likely to feel powerful. And the rational, self-interested thing to do when faced with police questioning is to stop it before it starts, to invoke one's Miranda rights as soon as the warnings are read.

155. See supra note 150 and accompanying text.

156. In Richard Leo's study, 38 out of 182 suspects invoked, but 36 of those invocations came at the beginning of questioning, not during questioning. Leo, supra note 27, at 653. The next best study shows a slightly higher but still very small percentage of invocations during questioning. See Paul G. Cassell \& Bret S. Hayman, Police Interrogation in the 1990s: An Empirical Study of the Effects of Miranda, 43 UCLA L. REV. 839, 859-60 (1996) (counting five such invocations out of 129 interrogations). 
This is what about twenty percent of suspects do. ${ }^{157}$ For those suspects, Miranda represents a complete ban on police questioning, a right to be free not just from coercive or abusive interrogation but from any interrogation. The other eighty percent are likely to be some combination of scared, ignorant, and irrational. If they were none of those things, they would probably refuse to give the police for free something for which the district attorney would happily pay with reduced charges or favorable sentencing recommendations. The very characteristics that lead these suspects to agree to talk to the police in the first place make it nearly impossible for them to call a halt to police questioning once it becomes uncomfortable. That is why no one invokes in response to coercive police questioning.

To put it another way, Miranda's goal is to separate police questioning into two categories-good and bad-and to penalize and thereby deter the bad kind. But Miranda does not do that. Instead, it separates suspects into two categories--talkative and quiet. Miranda has no discernible effect on how the police question the talkative ones. The quiet ones opt out of questioning altogether.

That twenty percent is the price the police pay for Miranda. It is not a high price. Few suspects are at once (1) guilty of very serious crimes, such that police would care a great deal about convicting them, (2) unconvictable without incriminating statements in the police station, and (3) savvy enough to invoke their Miranda rights. This helps to explain the general police satisfaction with Miranda. In eighty percent of the cases, it costs them nothing. The other twenty percent, they can either solve by other means or leave unsolved. The result is distributively unattractive-well-educated suspects and recidivists tend to gain at the expense of suspects with less education and less criminal experience ${ }^{158}$ - but that is unlikely to be a great concern to any particular police officer.

Unless the favored suspects might be terrorists. Local police no less than FBI agents are likely to care a great deal about whether they get information that enables them not just to solve past crimes but to prevent

157. Again, the best data are from Leo's work, which shows a prequestioning invocation rate of twenty percent (counting thirty-six such invocations out of 182 suspects). Leo, supra note 27 , at 653 .

158. Leo's study found that a suspect with a felony record was four times as likely to invoke as a suspect with no record, and three times as likely as a suspect with only a misdemeanor record. Richard A. Leo, Inside the Interrogation Room, 86 J. CRIM. L. \& CrIMINology 266, 286-87 (1996).

It is important to see that the gains and losses are reciprocal. Suppose that a prosecutor faccs a pool of ten cases, but has enough time to prosecute only five. Now suppose that, because of Miranda, two of the ten cases are suddenly harder to prosecute-there are no incriminating statements to introduce, so these two cases, while winnable, are riskier for the government than the other eight. The odds that the two Miranda winners will be prosecuted go down, while the odds that each of the other eight cases will be prosecuted go up. As long as prosecutors operate at capacity, meaning that they have more plausible cases to prosecute than they have time for, Miranda's winners will generate their own losers. 
the murder of large numbers of citizens. Terrorists tend not to be easily cowed or confused; they are therefore less likely to agree to talk to the police than are average suspects. ${ }^{159}$ The consequence is that Miranda's invocation rule, which caused only distributive injustice before September 11 , risks causing homicides after that date. Of course, the police can prevent that result by ignoring the invocation rule, but that has a high price as well: Suspects who may be guilty of terrible crimes may be effectively immune from prosecution. It wouldn't take many such cases-probably only one-to cause a public outcry. A few months ago, Miranda seemed unshakeable. Now, it may be untenable.

If so, a solution is ready at hand. Imagine that, instead of the current Miranda warnings, police at the outset of an interrogation told suspects something like the following: "You have the right to remain silent. Anything you say can be used against you in court. We have the right to ask you questions. You don't have to answer, but we get to ask. And this interrogation is going to be video- and audiotaped for your protection." The silent twenty percent of suspects would no longer enjoy their right to opt out of questioning. It seems likely that a fair number of them would talk, not because they were forced to but because it is much easier to ask for a lawyer once than to stay silent while police officers pepper you with questions and accusations. Those additional statements would be a gain not just for police and prosecutors, but for distributive justice as well: It would significantly reduce the advantage the savviest suspects have in the police station.

The other half of the trade is the video- and audiotape, which would allow defense lawyers to make informed arguments and judges to make informed judgments about the voluntariness of any incriminating statements their clients made. As things stand now, Miranda appears to do away with the need for judges to look carefully at the tactics police use to get confessions. If the warnings have been given and the suspect talked without invoking his rights, the reasoning goes, the police tactics must have been fair and the confession must have been voluntary. ${ }^{160} \mathrm{~A}$ return to the

159. See, e.g., HEYMANN, supra note 80 , at 111 ("In cases of political violence by members of a disaffected group, both loyalty to the cause and fear of retaliation are likely to discourage witnesses from coming forward."). For a discussion of how security forces in Northern Ireland dealt with this problem, see id. at 123-25. News reports shortly after the September 11 attacks indicate that the FBI has struggled with this problem in its efforts both to identify suspects in those attacks and to gather intelligence about planned future attacks. See, e.g., Walter Pincus, Silence of 4 Terror Probe Suspects Poses Dilemma for FBI, WASH. POST, Oct. 21, 2001, at A6 (quoting an FBI official as saying, "We're into this thing for 35 days and nobody is talking" and "frustration has begun to appear").

160. The idea that Miranda has perversely produced greater judicial deference to the police is now commonplace in the literature. For two early discussions, see Patrick A. Malone, "You Have the Right To Remain Silent": Miranda After Twenty Years, 55 AM. SCHOLAR 367, 377-79 (1986); and Louis Michael Seidman, Brown and Miranda, 80 CAL. L. REV. 673, 742-47 (1992). 
voluntariness standard (which is what the hypothetical warnings offered above would mean), this time with better evidence, would likely mean tougher judicial scrutiny than we see now.

Voluntariness with better evidence ought to be the police interrogation standard for all cases. At the least, though, we should adopt it for terrorism investigations. The alternative in such cases, after all, is not widespread compliance with Miranda. Noncompliance coupled with deceit is far likelier. If the information is important enough, police will surely ignore the invocation rule and question the suspect anyway. ${ }^{161}$ In this sense, interrogation in terrorism cases may resemble profiling - whatever the law says, there are some things the police are bound to do. Better to get the relevant police behavior out in the open than to maintain nominally strict rules that are ignored in practice.

The place where this logic runs out, and perhaps the place where legal compromises will likewise run out, is physical force. The Israeli security services and the British forces in Northern Ireland have famously used various forms of force and torture in the course of combating terrorism. ${ }^{162}$ It is reasonable to suspect that their analogues in the United States will want to do the same, and may already have done so. That raises a kind of question different from the others addressed in this Essay. I have been talking about police tactics and legal rules that are fundamentally contextual, the sorts of tactics and rules one might plausibly embrace in some times and places but not others. Torture is a different kind of tactic, as the law that forbids it is a different kind of law, a boundary that probably ought not to be crossed in any time or place. ${ }^{163}$ In times of rising crime, legal concessions to law enforcement are both inevitable and proper. But we need not concede everything.

161. Charles Weisselberg argues that police in California do this already in a wide range of cases. See Charles D. Weisselberg, Saving Miranda, 84 Cornell L. Rev. 109, 137 (1998).

162. For good, brief discussions, see, for example, HEYMANN, supra note 80, at 123-25, discussing Northern Ireland; and Catherine M. Grosso, Note, International Law in the Domestic Arena: The Case of Torture in Israel, 86 IOWA L. REV. 305, $311-18$ (2000), discussing Israel.

163. This conclusion seems at odds with the proposition advanced in Part I: that the legal boundaries in this area ought to depend on context, including the frequency and severity of the relevant crime problems. It would scem to follow from that proposition that if, for example, the terrorist threat is great enough and torture effective enough, we ought to authorize torture as a tool for interrogating suspected terrorists.

There are two responses. First, one can consistently believe that (1) some kinds of police tactics are always and everywhere wrong and (2) the rightness or wrongness of other tactics depends on circumstances. If any interrogation tactic is to be forbidden across the board, it is the infliction of severe physical pain for the purpose of obtaining information from the suspect. Second, even if torture were deemed permissible in principle in extreme cases, the extreme cases are rare enough, and the difficulty of limiting the practice to those cases great enough, that it makes sense to ban the practice without exception. It may be worth noting that even FBI agents, expressing frustration with their inability to get information from suspects in the wake of the September 11 attacks, suggested that torture should not be an option; they were more interested in using drugs as a tool for loosening suspects' tongues. See Pincus, supra note 159. 


\section{Conclusion: The Promise of a Grand Trade}

The preceding Sections have listed a series of regulatory swaps, pairs of rule changes that would both expand and restrict the scope of police power: broader authority to conduct group searches coupled with restrictions on the methods used to search individuals, broader authority to conduct secret searches coupled with limits on what the police can do with information they find in those searches, and broader power to question suspects coupled with a requirement that the questioning be recorded. If all these proposed changes became law, the net effect on the scope of police authority would be positive from the point of view of the police. Officers would be free to do more things than they can do now, and criminal investigations would probably be cheaper than they are now. At the same time, the net effect on individual freedom would also be positive. The interest in efficient law enforcement would gain, as would the interest in individual privacy and autonomy.

That happy result depends on movement in different directions on different legal fronts. One might fairly question whether such a thing is possible given the way the relevant bodies of law are made. Legislatures can pass complex statutes with multiple compromises. Appellate courts are poorly positioned to do that. Courts make law by deciding particular cases, and any one case raises a limited number of issues. No single Supreme Court decision could cover all or even most of the ground covered by the proposals I have offered in this Essay. It would seem to follow that a trade of the sort suggested here, with a series of paired changes in current constitutional doctrine, can't happen.

There is another reason why proposals like these might seem impractical. The Supreme Court changes direction often, but it generally moves in only one direction at a time. If a majority of the Justices believe the federal government is too powerful relative to the states, we can expect the kinds of federalism decisions the Court has handed down over the past half-dozen years. ${ }^{164}$ If, on the other hand, a majority believes federal power is too restricted, we can expect the kinds of nationalizing opinions the Court issued in the late 1930s and 1940s. ${ }^{165}$ One would not expect both at the

164. On the idea that the federal government cannot "commandeer" state and local officials, see Printz $v$. United States, 521 U.S. 898 (1997). On the limits the Commerce Clause places on federal power, see United States v. Morrison, 529 U.S. 598 (2000); and United States v. Lopez, 514 U.S. 549 (1995). On the limits Section 5 of the Fourteenth Amendment places on federal power, particularly when dealing with state employees, see Board of Trustees of the University of Alabama v. Garrett, 531 U.S. 356 (2001).

165. See, e.g., Wickard v. Filburn, 317 U.S. 111 (1942); United States v. Darby, 312 U.S. 100 (1941); United States v. Carolene Prods. Co., 304 U.S. 144 (1938); W. Coast Hotel v. Parrish, 300 U.S. 379 (1937). 
same time. Yet that is what a regulatory swap represents-more of one thing here, more of its opposite there.

There is a measure of truth to these arguments, but only a measure. The Supreme Court is a more flexible lawmaking body than one might suppose. And, on occasion, the Court has moved both on multiple fronts and in different directions at once.

Prime examples of both phenomena come from the most doctrinally creative decade in the Court's history: the 1960s. That decade saw a revolution in criminal procedure-a proper label given the range of areas where the Court's decisions substantially altered existing practices. Consider the following list: appellate review ${ }^{166}$ appointment of counsel, ${ }^{167}$ compulsory process, ${ }^{168}$ double jeopardy, ${ }^{169}$ habeas corpus, ${ }^{170}$ police interrogation, ${ }^{171}$ remedies for illegal searches, ${ }^{172}$ the right to cross-examine witnesses, ${ }^{173}$ the scope of the right to a jury, ${ }^{174}$ standards for arrest ${ }^{175}$ and wiretapping. ${ }^{176}$ In all of these areas the Court's decisions produced major change, either defining new conduct rules (as with Miranda's warnings and waiver doctrine) or setting the stage for larger changes to come (as with Gideon, which led to the growth of both public defenders' offices and ineffective assistance doctrine). Sometime around 1961, at least five Justices seem to have decided that the American criminal justice system needed reforming, and that political institutions were not up to the task of reforming it. Over the next decade (really only seven years ${ }^{177}$ ), the Court

166. See Chapman v. California, 386 U.S. 18 (1967) (defining the standard for harmless constitutional error).

167. See Gideon v. Wainwright, 372 U.S. 335 (1963) (granting the right to appointed counsel for criminal trials); Douglas v. California, 372 U.S. 353 (1963) (extending that right to criminal appeals).

168. See Washington v. Texas, 388 U.S. 14 (1967) (applying the compulsory process requirement to state cases).

169. See Benton v. Maryland, 395 U.S. 784 (1969) (applying the ban on double jeopardy to state cases).

170. See Fay v. Noia, 372 U.S. 391 (1963) (establishing a lenient procedural default standard for federal habeas review of state court convictions).

171. See Miranda v. Arizona, 384 U.S. 436 (1966) (establishing, in effect, a code of police interrogation, with detailed warnings and strict waiver standards).

172. See Mapp v. Ohio, 367 U.S. 643 (1961) (applying the exclusionary rule to state cases); Monroe v. Pape, 365 U.S. 167 (1961) (broadening damages liability for constitutional violations).

173. See Bruton v. United States, 391 U.S. 123 (1968) (barring the admission of an accomplice's out-of-court confession at the defendant's trial).

174. See Duncan v. Louisiana, 39 I U.S. 145 (1968) (applying the right to jury trial in serious criminal cases to the states).

175. Beck v. Ohio, 379 U.S. 89 (1964), barred the police from using evidence obtained after arrest to justify the arrest. Shuttlesworth v. Birmingham, 382 U.S. 87 (1965), made it harder to justify arrests by reference to broad, catchall crimes like loitering or vagrancy.

176. See Katz v. United States, 389 U.S. 347 (1967) (holding that taps of public telephones are "searches" subject to the Fourth Amendment's warrant requirement); Berger v. New York, 388 U.S. 41 (1967) (placing various restrictions including, but not limited to, probable cause and warrant requirements on taps of private telephones).

177. Almost all the relevant decisions came between 1961 and 1968. See supra notes 166176. 
undertook a nearly comprehensive reform of the system-just the sort of thing an omnibus legislative package might have done. ${ }^{178}$ So much for the inability to move on multiple fronts at once.

These judicial reforms all seemed to move in the same direction: toward greater limits on government power and greater protections for individual rights. ${ }^{179}$ That picture changes, however, if one broadens the sphere of vision. Consider not only constitutional criminal procedure, but all the bodies of constitutional law that define and restrict the scope of government power to act on individuals. On the one hand, the 1960s saw that power limited in a host of ways-the criminal procedure decisions mentioned in the last paragraph are examples, as are some of the Court's First Amendment ${ }^{180}$ and due process cases. ${ }^{181}$ On the other hand, the Court enlarged the government's power to regulate private discrimination with expansive interpretations of the Commerce Clause, ${ }^{182}$ Section 5 of the Fourteenth Amendment, ${ }^{183}$ and Section 2 of the Thirteenth Amendment. ${ }^{184}$ Both developments had large effects, but one limited the government's authority while the other removed legal and customary limits that had long been in place. So much for the inability to move in different directions at once.

The kinds of changes I have proposed are both more modest and less complicated than the legal changes mentioned in the preceding two paragraphs. The fact that the larger and more complex changes were within the Supreme Court's capacity suggests that the smaller and simpler ones are as well.

The real obstacle to productive change in this area is not incapacity but a lack of imagination. The Court of the 1960s crafted a large constitutional code of police conduct (which is part of an even larger constitutional code

178. Indeed, at around the same time, legislatures were undertaking a comprehensive reform of the law that defines crimes, with the Model Penal Code triggering large-scale revision of a couple dozen state criminal codes. See MODEL PENAL CODE, at xi (Official Draft and Revised Comments 1985) (listing thirty-four states that had revised their criminal codes between 1962 and 1983). A comparison of the two reform movements is interesting. I think it is fair to say that the Supreme Court's reform of criminal procedure was a good deal more extensive-involving a good deal more and more consequential change in legal doctrine-than the ALI-prompted reform of criminal law.

179. At least that was the clear intent. The effect of the Warren Court's criminal procedure decisions was rather different. For extended discussions, see sources cited infra note 185.

180. On political speech, see Brandenburg v. Ohio, 395 U.S. 444 (1969). On artistic speech, though it is slightly outside the relevant time frame, see Roth v. United States, 354 U.S. 476 (1957).

181. With respect to substantive due process, see Griswold v. Connecticut, 381 U.S. 479 (1965). With respect to the procedural variety (though it is slightly beyond the 1960s), see Goldberg v. Kelly, 397 U.S. 254 (1970).

182. See Heart of Atlanta Motel, Inc. v. United States, 379 U.S. 241 (1964); Katzenbach v. McClung, 379 U.S. 294 (1964).

183. See Katzenbach v. Morgan, 384 U.S. 641 (1966).

184. See Jones v. Alfred H. Mayer Co., 392 U.S. 409 (1968). 
of criminal procedure). It did so with little attention to constitutional text or precedent, both of which cut against most of the major decisions of the period. That code is dysfunctional; it imposes substantial costs on government institutions without providing substantial protection for criminal suspects and defendants. ${ }^{185}$ Maintaining and even extending it in the interest of fidelity to text and precedent-which roughly describes the current Court's posture toward criminal procedure ${ }^{186}$-makes no sense: It is an act of fidelity to precedents that are themselves unfaithful, while the relevant constitutional texts offer only unhelpful generalities. What is needed is another burst of 1960s-style judicial creativity, to remedy the effects of the last such burst of creativity.

A movement to reform the Warren Court's reforms, to overhaul the bodies of constitutional law that police the police, is long overdue. Perhaps the terrible crimes committed in New York and Washington will bring such a movement into being. Perhaps the calls for more law enforcement power will lead judges and Justices to think about ways in which those calls might be heeded while still advancing the cause of individual liberty. That would not be nearly enough to redeem the thousands murdered on that Tuesday last September. But it might be one of the best things that malignant day could produce.

185. This proposition holds for criminal procedure as a whole, not just for the range of Fourth and Fifth Amendment issues discussed in this Essay. Scholars in the field, regardless of their differing views on the proper direction of legal reform, increasingly agree that the law in this field is dysfunctional. See, e.g., AKHIL REED AMAR, ThE CONSTITUTION AND CRIMINAL PROCEDURE (1997) (advocating a retum to the original understanding of the Fourth, Fifth, and Sixth Amendments); Donald A. DRIPPS, Criminal Procedure as Constitutional Law (forthcoming 2002) (advocating the abandonment of incorporation and a return to due process analysis); WILLIAM T. PIZZI, TRIALS WITHOUT TRUTH (1999) (advocating greater emphasis on accuracy and the truth-finding function of criminal trials); Stuntz, supra note 146 (advocating less constitutional regulation of procedure and more regulation of substantive criminal law and the funding of criminal defense counsel).

186. For the best recent example, see Dickerson v. United States, 530 U.S. 428 (2000). 